\title{
Profilin 1 Associates with Stress Granules and ALS-Linked Mutations Alter Stress Granule Dynamics
}

\author{
Matthew D. Figley, ${ }^{1,2}$ Gregor Bieri, ${ }^{1,2}$ Regina-Maria Kolaitis, ${ }^{3}$ J. Paul Taylor, ${ }^{3}$ and Aaron D. Gitler ${ }^{1}$ \\ ${ }^{1}$ Department of Genetics and ${ }^{2}$ Neuroscience Graduate Program, Stanford University School of Medicine, Stanford, California 94305, and ${ }^{3}$ Department of \\ Cell and Molecular Biology, St Jude Children's Research Hospital, Memphis, Tennessee 38105
}

\begin{abstract}
Mutations in the PFN1 gene encoding profilin 1 are a rare cause of familial amyotrophic lateral sclerosis (ALS). Profilin 1 is a well studied actin-binding protein but how PFN1 mutations cause ALS is unknown. The budding yeast, Saccharomyces cerevisiae, has one PFN1 ortholog. We expressed the ALS-linked profilin 1 mutant proteins in yeast, demonstrating a loss of protein stability and failure to restore growth to profilin mutant cells, without exhibiting gain-of-function toxicity. This model provides for simple and rapid screening of novel ALS-linked PFN1 variants. To gain insight into potential novel roles for profilin 1, we performed an unbiased, genome-wide synthetic lethal screen with yeast cells lacking profilin $(p f y 1 \Delta)$. Unexpectedly, deletion of several stress granule and processing body genes, including $p b p 1 \Delta$, were found to be synthetic lethal with $p f y 1 \Delta$. Mutations in ATXN2, the human ortholog of PBP1, are a known ALS genetic risk factor and ataxin 2 is a stress granule component in mammalian cells. Given this genetic interaction and recent evidence linking stress granule dynamics to ALS pathogenesis, we hypothesized that profilin 1 might also associate with stress granules. Here we report that profilin 1 and related protein profilin 2 are novel stress granule-associated proteins in mouse primary cortical neurons and in human cell lines and that ALS-linked mutations in profilin 1 alter stress granule dynamics, providing further evidence for the potential role of stress granules in ALS pathogenesis.
\end{abstract}

Key words: ALS; PFY1; profilin 1; stress granules; yeast

\section{Introduction}

Amyotrophic lateral sclerosis (ALS) is a fatal neurodegenerative disease characterized by motor neuron loss (Cleveland and Rothstein, 2001). The mechanisms of motor neuron degeneration in ALS remain poorly understood. However, recent studies have contributed to revealing the genetic underpinnings of ALS. Since 2008, the discoveries of new causative familial ALS (FALS) genes, including TARDBP, FUS/TLS, OPTN, UBQLN2, VCP, hnRNPA2B1, hnRNPA1, and C9ORF72 (Renton et al., 2014) and common genetic risk factors for sporadic ALS such as ATXN2 (Elden et al., 2010) have expanded the genetic

\footnotetext{
Received Feb. 7, 2014; revised April 7, 2014; accepted May 5, 2014.

Author contributions: M.D.F., G.B., R.-M.K., J.P.T., and A.D.G. designed research; M.D.F., G.B., and R.-M.K. performed research; M.D.F., G.B., R.-M.K., J.P.T., and A.D.G. analyzed data; M.D.F. and A.D.G. wrote the paper.

This work was supported by NIH Director's New Innovator Award 1DP20D004417, NIH Grant NS065317, and Muscular Dystrophy Association Grant MDA294366. R.M.K. is supported by the ALS Association and J.P.T. by Target ALS. A.D.G. is supported by the Packard Center for ALS Research and Target ALS. M.D.F. is supported by the Stanford Genome Training Program (NIH 5T32HG000044-17). G.B. is supported by the Stanford Graduate Fellowship. We thank Erfei Bi (University of Pennsylvania) for providing some yeast profilin mutant strains and for helpful suggestions; Roy Parker (University of Colorado Boulder) for providing the yeast Pab1-GFP/Edc3-mCherry plasmid; Thomas Ward and Julien Couthouis for generating the pfy $1 \Delta$ (pfy1 $:: n a t M X)$ yeast strain; Ana Jovičic for help with mouse primary neuron isolation and culture; Nripesh Dhungel for help with the yeast screen; the Gitler laboratory for helpful discussions and critical reading of the paper; Mary Leonard (University of Pennsylvania) for help illustrating Fig. $3 B_{\text {; }}$ and the Vector Development and Production, SJCRH for providing the pCLEG-MND-dsRedEX2 plasmid and the transduction of the lentivirus.

The authors declare no competing financial interests.

Correspondence should be addressed to Dr Aaron D. Gitler, 300 Pasteur Drive, M322 Alway Building, Stanford, CA 94305.E-mail: agitler@stanford.edu.

DOI:10.1523/JNEUROSCI.0543-14.2014

Copyright $\odot 2014$ the authors $\quad 0270-6474 / 14 / 348083-15 \$ 15.00 / 0$
}

landscape of the disease, illuminating common pathways such as impairments in RNA metabolism and protein homeostasis (Ling et al., 2013).

Profilin 1 is a small $(15 \mathrm{kDa})$ actin-binding protein known to influence actin filament dynamics and carry out various cellular functions via preferential binding to phosphoinositides and a variety of polyproline-rich ligands (Jockusch et al., 2007). Recently, Landers and colleagues found mutations in the profilin 1 gene PFN1 to be causative of FALS (Wu et al., 2012). The discovery of ALS-linked PFN1 mutations highlights the potential role of the actin cytoskeleton in ALS pathogenesis. Subsequent sequencing efforts in independent ALS populations have discovered additional PFN1 variants (Ingre et al., 2012; Lattante et al., 2012; Tiloca et al., 2012; Chen et al., 2013; Daoud et al., 2013; Dillen et al., 2013; Yang et al., 2013; Zou et al., 2013; van Blitterswijk et al., 2013), and have suggested that the E117G variant may be an ALS risk factor (Fratta et al., 2014). The mechanism by which PFN1 mutations cause ALS and how profilin 1 function may relate to other cellular pathways implicated in ALS pathogenesis remain unresolved.

The power of yeast genetics has recently been unleashed to study the mechanisms of human neurodegenerative diseases, with yeast models to study Parkinson disease, Huntington disease, Alzheimer disease, frontotemporal dementia, and ALS yielding important insights into disease pathophysiology (Outeiro and Lindquist, 2003; Cooper et al., 2006; Gitler, 2008, 2009; Elden et al., 2010; Couthouis et al., 2011; Sun et al., 2011; Treusch et al., 2011; Armakola et al., 2012; Tardiff et al., 2013). Here we 
describe a yeast model to examine possible gain- or loss-offunction mechanisms related to the ALS-linked variants of profilin 1 . We establish a rapid platform to assess the effect of the existing ALS-linked PFN1 variants as well as evaluate any newly discovered candidate variants. Additionally, we perform an unbiased genetic screen and discover an unexpected, novel role for profilin 1 in ribonucleoprotein (RNP) granules, cytoplasmic RNA-protein assemblies which are emerging as potential crucibles of ALS pathogenesis (Li et al., 2013). Further, we show that profilin 1 associates with stress granules in diverse mammalian cell types, including primary rodent neurons, under an array of cellular stresses. Finally, we demonstrate that ALS-linked PFN1 mutations alter stress granule dynamics, providing a potential mechanism to explain their role in disease.

\section{Materials and Methods}

Yeast strains, media, and plasmids. We generated the $p f y 1 \Delta$ query strain by replacing the $P F Y 1$ coding region with the natMX resistance cassette in

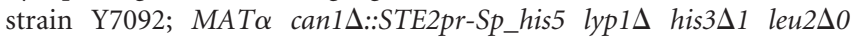
ura $3 \Delta 0$ met $15 \Delta 0$. We used colony PCR to verify correct gene disruption. Strains were grown at $30^{\circ} \mathrm{C}$ on YPD or complete synthetic medium. Strains were manipulated and media prepared using standard techniques.

pfyls synthetic lethal screen. We used synthetic genetic array (SGA) analysis to identify nonessential yeast deletions that are synthetic lethal with $p f y 1 \Delta$. We performed this screen essentially as described by Tong and Boone (2006), with some modifications, using a Singer RoToR HDA (Singer Instruments). We mated the MAT $\alpha f y 1 \Delta$ query strain to the yeast haploid deletion collection of nonessential genes ( $M A T a$, each gene deleted with kanMX cassette; confers resistance to G418). Our yeast nonessential gene deletion library contains $4842 / \sim 6000$ yeast genes. Following diploid selection and sporulation, we selected double-mutant haploids. Colony sizes were measured using the HT Colony Grid Analyzer software (Collins et al., 2006). The colony size raw values for each plate were normalized, dividing them by the median colony size of that plate. For every yeast strain, the colony size of the two replicates per plate was averaged and duplicate colonies that differed in size more than their average size were excluded from analysis. Additionally, slow growing single-deletion strains were excluded as well. The colony size of the single- and double-deletion yeast strains were compared. A 50\% reduction in colony size of the double-deletion strains was chosen as the threshold for synthetic lethal/sick interactions. All hits as well as all excluded strains were visually inspected and confirmed. The entire screen was performed four independent times. Hits that repeatedly satisfied the criteria for synthetic lethal interactions were used for gene ontology enrichment analysis.

Yeast experiments. Yeast profilin mutant strains pfy1-4 (MATa his3 200 leu2-3,112 lys2-801 pfy1-4::LEU2 ura3-52) and pfy1D (MATa

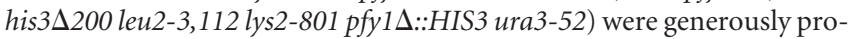
vided by Erfei Bi (University of Pennsylvania) and were described by Wolven et al. (2000). We also used the wild-type yeast strain BY4741 (MATa his $3 \Delta 0$ leu2 $\Delta 0$ met $15 \Delta 0$ ura3 $\Delta 0$ ). We obtained the yeast profilin (PFY1) entry clone construct from the Yeast FLEXGene library (Harvard Institute of Proteomics). A human PFN1 Gateway entry clone was obtained from the Human ORFeome collection (Open Biosystems), containing the full-length human PFN1 coding sequence in the vector pDONR223. This clone lacked a stop codon so we introduced one by PCR amplifying the PFN1 coding sequence with primers to add flanking Gateway cloning sites and a C-terminal stop codon. We then performed a Gateway BP reaction to shuttle the PFN1 coding sequence with stop codon into the vector pDONR221. A human profilin 2 (PFN2) Gateway entry clone was obtained from the Human ORFeome collection (Open Biosystems), containing the full-length human PFN2 coding sequence in the vector pDONR223. The QuikChange site-directed mutagenesis system (Stratagene) was used to introduce a stop codon into this construct, as well as to introduce point mutations into the PFN1 constructs. All constructs were verified by DNA Sanger sequencing. To generate PFY1,
PFN1, or PFN2 yeast expression constructs, we used a Gateway LR reaction with the appropriate entry clones and a yeast Gateway destination vector (e.g., pAG416GPD-ccdB or pAG426Gal-ccdB; Alberti et al., 2007). Yeast procedures were performed according to standard protocols. We used the PEG/lithium acetate method to transform yeast with plasmid DNA (Gietz et al., 1992). For spotting assays, yeast cells were grown overnight at $30^{\circ} \mathrm{C}$ in rich media (YPD) or in synthetic liquid media containing SD/-Ura or SRaf/-Ura until they reached log or mid-long phase. Cultures were then normalized for OD600 nm, serially diluted and spotted with a Frogger (V\&P Scientific) onto synthetic solid media containing glucose (SD/-Ura) or galactose (SGal/-Ura) lacking uracil and were grown at 25,30 , or $37^{\circ} \mathrm{C}$ for $2-4 \mathrm{~d}$. For yeast stress granule experiments, yeast cells were transformed with a plasmid encoding stress granule marker Pab1-GFP and processing body (P-body) marker Edc3-mCherry (pRP1657; Buchan et al., 2010). Yeast were grown to mid-log phase at $30^{\circ} \mathrm{C}$ then subjected to $15 \mathrm{~min}$. continued growth at $30^{\circ} \mathrm{C}$ or heat shock at $42^{\circ} \mathrm{C}$. Yeast were plated onto microscope slide with coverslip and imaged at $100 \times$ magnification (with an additional $1.6 \times$ internal magnification) with a fluorescence microscope. Live yeast cells were imaged within $15 \mathrm{~min}$ of addition to the slide to avoid additional cellular stress.

Cell culture. HeLa cells (CCL-2) and U2OS cells were obtained from ATCC. HeLa, U2OS, and U2OS-G3BP-GFP cells were maintained in DMEM, High Glucose, GlutaMAX (Invitrogen, no. 10566) with 10\% fetal bovine serum, $1 \%$ penicillin/streptomycin, and $1 \mathrm{~mm}$ sodium pyruvate (Invitrogen, no. 11360070). Mouse primary cortical neurons were dissected from E18 embryos and dissociated using papain. Neurons were maintained in neurobasal media supplemented with B27 and $0.5 \mathrm{~mm}$ L-glutamine. Neurons were treated at $7 \mathrm{~d}$ in vitro. Cells were seeded in 24-well plates on glass coverslips precoated with poly-L-lysine (HeLa), poly-L-orinthine with laminin and fibronectin (neurons), or on 8-well glass slides (Millipore, PEZGS0816; U2OS-G3BP-GFP). The N-terminal V5-tagged plasmids were generated by Gateway LR reactions with the pDONR221 profilin 1 entry clones and the pcDNA3.1/nV5-DEST Gateway destination vector (Invitrogen, Catalog \#12290010). Cells were transfected with plasmid DNA using FuGENE6 Transfection Reagent (Promega, E2691). PFN1 RNAi knockdown was performed by transfection of ON-TARGET plus-SMARTpool siRNA (Dharmacon; L-012003 for human cells) using Lipofectamine RNAiMAX reagent (Invitrogen). RNAi knockdown for nontargeting was performed by transfection of ON-TARGET plus-SMARTpool siRNA (Dharmacon; 1081195) using Lipofectamine RNAiMAX (Invitrogen). Cells were treated with the following stressors: $0.5 \mathrm{~mm}$ sodium arsenite for $30 \mathrm{~min}$ (U2OS-G3BP-GFP) or $1 \mathrm{~h}$ (HeLa, neurons); $1 \mathrm{~h}$ (HeLa, neurons), or $2 \mathrm{~h}$ (U2OS-G3BP-GFP) $43^{\circ} \mathrm{C}$ heat shock; $1 \mathrm{~h} 2 \mathrm{~mm}$ dithiothreitol (DTT); 1 h $50 \mu \mathrm{g} / \mathrm{ml}$ cycloheximide. At $48 \mathrm{~h}$ post-transfection, cells were fixed using $4 \%$ formaldehyde at room temperature for $10 \mathrm{~min}$ and then washed $3 \times$ in PBS.

Stable cell line. U2OS cells stably expressing G3BP-GFP were generated by lentiviral transduction of a pCLi40w-MND-G3BP-GFP plasmid. The pCLi40w-MND-G3BP-GFP plasmid was constructed by releasing the dsRedEX2-EIF1 $\alpha$-GFP from the pCLEG-MND-dsRedEX2 plasmid (Vector Development and Production, SJCRH) and inserting the G3BPGFP into the EcoRI and BsrGI positions. The G3BP-GFP insert was released from the peGFP-N1-G3BP plasmid by digestion of EcoRI and BsrGI. The G3BP sequence had been inserted in the peGFP-N1 vector (Clontech) with primers containing the restriction enzyme sites EcoRI and $\mathrm{BamHI}$ in the $5^{\prime}$ and $3^{\prime}$ sites of G3BP. The lentivirus was prepared in HEK293 cells, plated at $1 \times 10^{5}$ cells per well in a 6-well dish in DMEM $+10 \%$ FCS (D10). Each transduction was performed in $1 \mathrm{ml}$ total volume, which is composed of D10, $8 \mu \mathrm{g} / \mathrm{ml}$ polybrene (Sigma-Aldrich Sequabrene Catalog \#S2667), and varying dilutions of vector; 10, 1, and $0.1 \mu \mathrm{l}$ of vector were added in the $1 \mathrm{ml}$ final volume. Forty-eight hours after transduction the virus was collected, filtered, aliquoted, and stored at $-80^{\circ} \mathrm{C}$. Different concentrations of viruses were titered on U2OS cells. Several stable cell lines with different expression levels of G3BP-GFP were tested and analyzed. The selected cell line reported here has G3BP-GFP protein expression levels lower than the endogenous levels of G3BP protein.

Immunocytochemistry. For immunostaining, fixed cells were blocked for $1 \mathrm{~h}$ in $5 \%$ normal goat serum and $0.25 \%$ Triton X-100 in PBS and 
were incubated in the same solution for $1 \mathrm{~h}$ at room temperature or overnight at $4^{\circ} \mathrm{C}$ with primary antibody [rabbit anti-profilin 1 (SigmaAldrich, no. P7624, 1:500), rabbit anti-profilin-2 (Sigma-Aldrich, no. P0101, 1:250), mouse anti-ataxin 2 (BD, no. 611378, 1:250), mouse antiHuR (Santa Cruz Biotechnology, no. sc-5261, 1:500), rabbit anti-V5 (Sigma-Aldrich, no. V8137, 1:500), rabbit anti-eIF4G (Santa Cruz Biotechnology, no. sc-11373, 1:500)] washed $3 \times$ in PBS, and incubated for $1 \mathrm{~h}$ with secondary antibody (AlexaFluor 488, 594, or 647 goat antimouse or anti-rabbit IgG $(\mathrm{H}+\mathrm{L})$, Invitrogen), washed $3 \times$ in PBS, and mounted on microscope slides using mounting media with $4^{\prime}, 6-$ diamidino-2-phenylindole (DAPI) to stain nuclei (ProLong Gold antifade reagent, no. P36834, Invitrogen). Immunostaining was observed and imaged using a Leica DMI6000B Inverted Fluorescence microscope with a coverslip-corrected $40 \times$ oil objective and a LSM510 (Zeiss) confocal microscope with a $63 \times$ objective. Representative images were compiled using ImageJ and Photoshop. Quantifications were statistically evaluated by the paired Student's $t$ test. A minimum of 100 transfected cells per condition were quantified per replicate experiment.

Immunoblotting. Yeast cells were grown to mid-log phase and lysed using Y-PER Plus Extraction Reagent (Thermo, no. 78999) with $1 \times$ Halt Protease Inhibitor Cocktail. Lysates were subjected to SDS/PAGE (NuPAGE Bis-Tris $4-12 \%$ gradient, Novex) and transferred to a nitrocellulose membrane (Invitrogen). Membranes were blocked with 5\% nonfat dry milk (for HRP detection) or $1 \%$ bovine serum albumin (for fluorescent detection) in PBS for $1 \mathrm{~h}$ at room temperature or overnight at $4^{\circ} \mathrm{C}$. Primary antibody incubations were performed at room temperature for $1 \mathrm{~h}$ or overnight at $4^{\circ} \mathrm{C}$. After washing with PBS, membranes were incubated with a horseradish peroxidase-conjugated secondary antibody for $1 \mathrm{~h}$ at room temperature, followed by washing in PBS and detected with Immobilon Western HRP Chemiluminescent Substrate (Millipore), or incubated with fluorescently labeled secondary antibodies (AlexaFluor 680 Goat anti-rabbit IgG or anti-mouse IRDye $800 \mathrm{CW}$ ) and detected using an Odyssey Scanner (Li-Cor). Antibody concentrations used were as follows: rabbit anti-profilin 1 (Sigma-Aldrich, P7624) 1:1000; rabbit anti-PFN2 (Sigma-Aldrich, P0101) 1:2000; mouse anti-GAPDH (SigmaAldrich, G8795) 1:4000; mouse anti- $\beta$-actin (Sigma-Aldrich, A5316) 1:1000. The HRP-conjugated anti-mouse secondary antibody (SigmaAldrich) was used at 1:10,000 and the HRP-conjugated anti-rabbit secondary antibody (Sigma-Aldrich) was used at 1:5000. The fluorescent secondary antibodies were used at 1:15,000. Western blots were quantified using ImageJ software.

\section{Results}

Yeast model to test candidate PFN1 variants

PFN1 is highly conserved through evolution with a clear ortholog present in budding yeast (Ostrander et al., 1999). Mutations in yeast profilin (PFY1) cause a temperature-sensitive (ts) growth phenotype such that mutant cells can grow at 25 or $30^{\circ} \mathrm{C}$ but not at $37^{\circ} \mathrm{C}$ (Fig. $1 A$; Wolven et al., 2000). This ts phenotype afforded us the opportunity to (1) confirm that PFN1 can complement the yeast profilin mutant phenotype (Ostrander et al., 1999), and (2) test whether the ALS-linked PFN1 mutations cause a loss of protein function (i.e., unable to rescue the $p f y 1 \Delta$ ts growth phenotype). For these studies we used two independent profilin mutant yeast strains: $p f y 1-4$, which harbors a point mutation that disrupts actin binding, and $p f y 1 \Delta$, a complete deletion (Wolven et al., 2000). Both strains exhibited similar ts phenotypes, but the complete deletion $(p f y 1 \Delta)$ grew slightly slower than the point mutant ( $p f y 1-4)$. We transformed $p f y 1 \Delta$ and $p f y 1-4$ strains with low-copy plasmids constitutively expressing either the yeast or human profilin genes. At $37^{\circ} \mathrm{C}$, expression of either yeast Pfyl or human PFN1 was sufficient to restore growth to the mutant strains (Figs. $1 B, 2 A$ ). These results confirm that the function of PFN1 is conserved from yeast to human and provide a simple platform to interrogate the effects of disease-linked human PFN1 variants.

Next, we used this same assay to test all of the recently reported ALS-linked PFN1 variants (Ingre et al., 2012; Wu et al.,
A

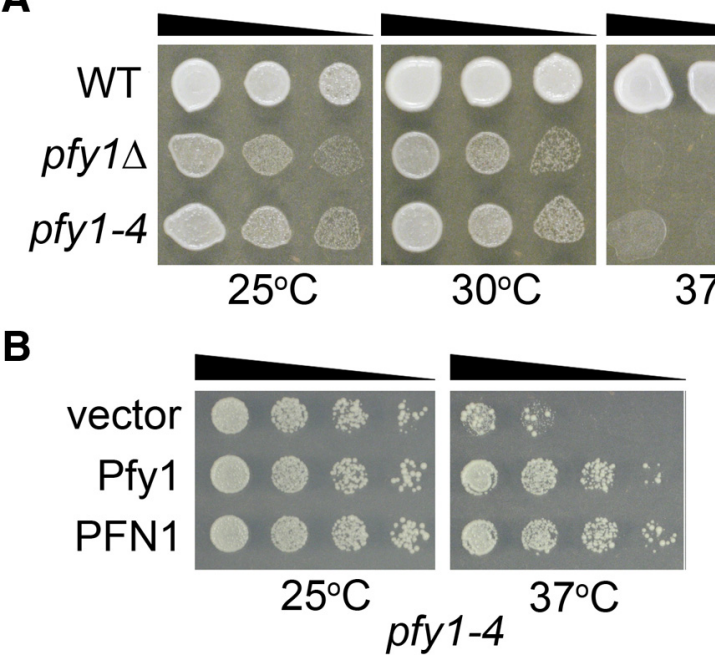

Figure 1. Human profilin 1 rescues yeast profilin mutant ts phenotype. $A$, Spotting assay to assess growth of WT, pfy $1 \Delta$, or pfy $1-4$ yeast strains at 25,30 , or $37^{\circ} \mathrm{C}$. The PFY 1 mutant strains are unable to grow at $37^{\circ} \mathrm{C}$. Each spot of yeast cells is sequentially diluted $5 \times$ from left to right. $\boldsymbol{B}$, Expressing WT yeast Pfy1 or human PFN1 is sufficient to restore growth at $37^{\circ} \mathrm{C}$.

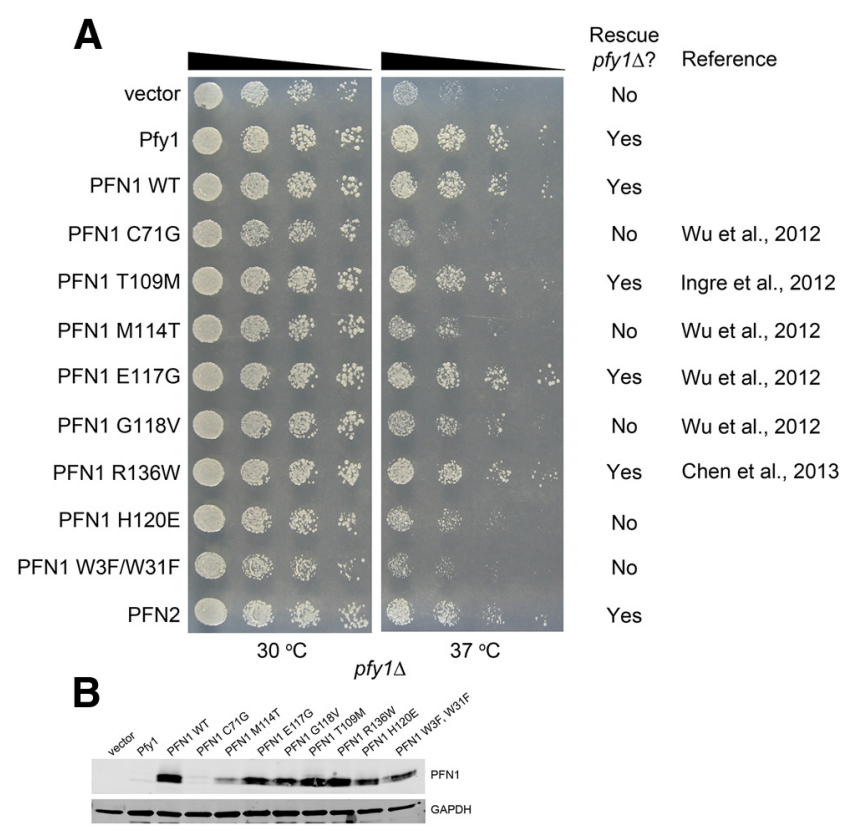

Figure 2. Testing ALS-linked profilin 1 variants in yeast. $\boldsymbol{A}$, Spotting assay to compare ability of several ALS-linked profilin 1 variants to rescue growth of pfy $1 \Delta$ at $37^{\circ} \mathrm{C}$. WT profilin 1 restores growth, as do profilin 1 variants $\mathrm{T109M}, \mathrm{E} 117 \mathrm{G}$, and R136W, suggesting that these profilin 1 variants are not deleterious to profilin 1 function in this assay. Profilin 1 variants C71G, M114T, and G118V do not rescue growth, suggesting that these disease-associated mutations impair profilin 1 function. Two synthetic profilin 1 mutants, H120E and W3F/W31F, which disrupt actin binding and polyproline-binding, respectively, also fail to rescue growth. The related human profilin gene profilin 2 (PFN2) is also able to rescue growth impairment of the pfy $1 \Delta$ yeast strain. $\boldsymbol{B}$, Immunoblot analysis of WT and mutant profilin 1 expression in yeast. The $\mathrm{C} 71 \mathrm{G}$ and M114T profilin 1 mutations affected expression levels or protein stability compared with the WT protein.

2012; Chen et al., 2013). Whereas WT profilin 1 restored growth, ALS-linked profilin 1 mutants C71G, M114T, and G118V were unable to rescue the ts phenotype of the yeast profilin mutant strains (Fig. 2A), suggesting that these ALS-linked mutations cause a loss-of-function. Immunoblotting with a human antiprofilin 1 antibody indicated that the C71G and M114T muta- 
tions affected expression levels or protein stability compared with the WT protein (Fig. 2B). Interestingly, the E117G mutation, which was present in both ALS cases and healthy controls (Wu et al., 2012), was well expressed and able to rescue the growth defect to a similar extent as WT human profilin 1 (Fig. 2A). These results support the conclusion that E117G may be less pathogenic than the other mutations (Wu et al., 2012). We also tested two profilin 1 mutations that have been identified by sequencing studies in ALS patients (T109M and R136W; Ingre et al., 2012; Chen et al., 2013). Both mutants were well expressed and were able to rescue the pfy $1 \Delta$ growth defect (Fig. $2 A, B$ ). Finally, we tested two artificial PFN1 variants, H120E previously shown to abolish actin binding (Suetsugu et al., 1998), and a double-mutant W3F/W31F, which abolishes binding to polyproline-rich ligands (Ostrander et al., 1999). Both the actin-binding and the polyprolinebinding deficient mutants serve as negative controls in our assay, as they are well expressed in yeast but demonstrate severe loss-of-function, as previously reported for W3F/W31F (Ostrander et al., 1999; Fig. 2A). As additional PFN1 variants are identified by sequencing studies, it will be important to distinguish damaging from benign variants, especially if family segregation data are not available. This yeast model, and the positive and negative controls reported here could provide a rapid screening platform for testing the consequences of such variants on profilin 1 function.

All of the major genes associated with FALS are inherited in a dominant fashion (Renton et al., 2014) and several mutations in these genes can confer gain-offunction toxic properties (Bruijn et al., 1998; Johnson et al., 2009; Barmada et al., 2010; Sun et al., 2011). We next tested whether ALS-linked profilin 1 proteins demonstrate a toxic gain-of-function effect in yeast. We transformed WT yeast cells with high-copy plasmids containing WT or mutant human profilin 1 under control of a strong galactose-inducible promoter. We did not observe any toxicity with WT or ALSlinked profilin 1 variant overexpression in this assay (data not shown). These results suggest that, at least in yeast, ALS-linked mutations in profilin 1 do not cause gain-of-function toxic properties. Although a toxic gain-of-function disease mechanism should not be ruled out for these ALS-linked profilin 1 mutants, this mechanism cannot be modeled using the yeast system.

\section{Yeast synthetic lethal screen to identify novel profilin functions}

The yeast model system offers several experimental advantages. Chief among them is the ability to rapidly perform unbiased

A

B
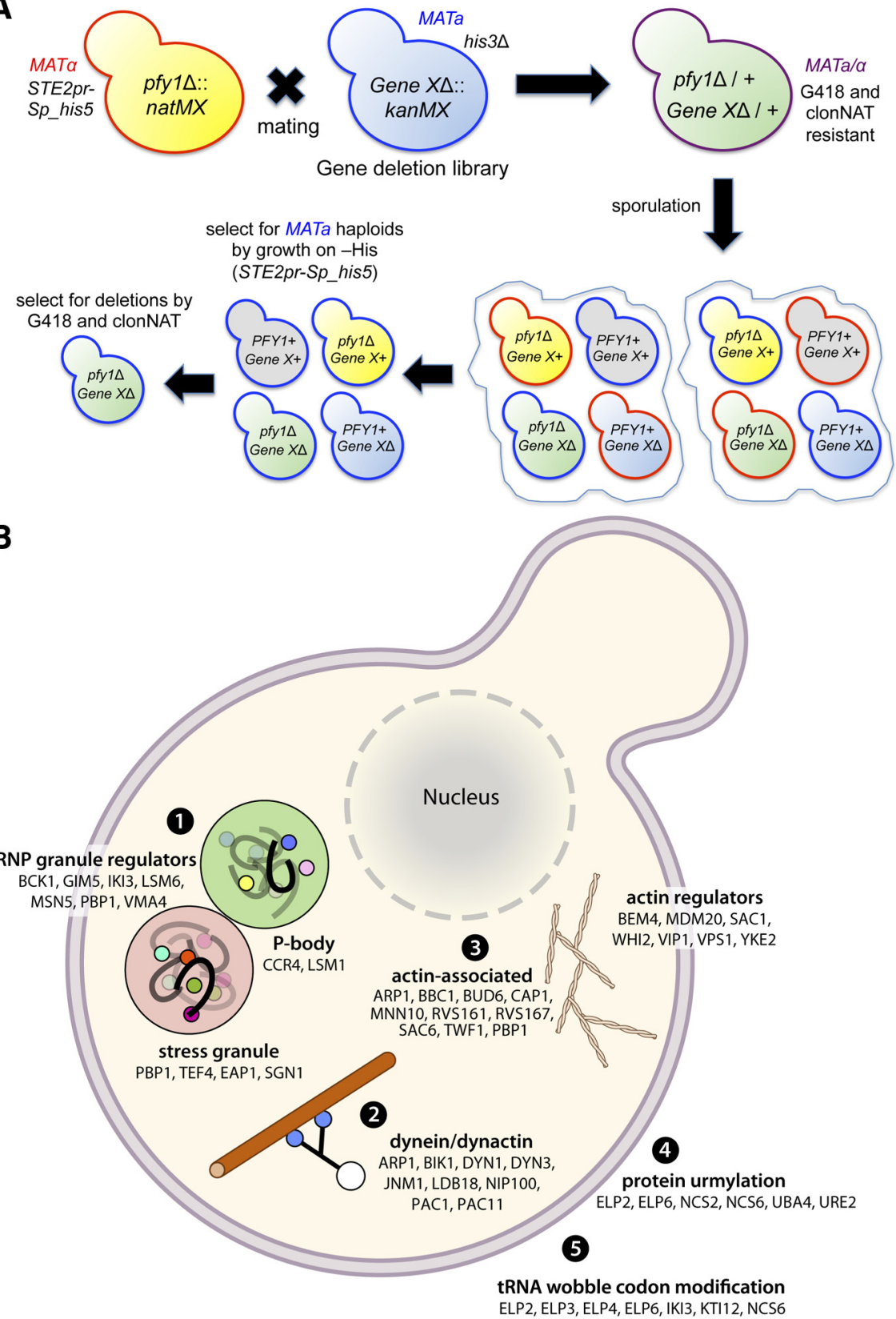

Figure 3. pfy $1 \Delta$ synthetic lethal screen. $\boldsymbol{A}$, Schematic of yeast deletion screen. MAT $\alpha$ strain harboring a PFY1 deletion ( pfy1D::natMX) was mated to each strain in the yeast haploid deletion collection of nonessential genes (MATa, each gene deleted with kanMX cassette; confers resistance to G418). Mating, sporulation, and mutant selection were performed based on (Tong et al., 2001). Following growth at $30^{\circ} \mathrm{C}$ for $2 \mathrm{~d}$, plates containing single (pfy $1 \Delta$ ) or double ( pfy $1 \Delta x x x \Delta$ ) mutants were photographed and colony sizes measured by HT Colony Grid Analyzer software, based on (Collins et al., 2006). B, A schematic of a yeast cell highlighting categories of genes that were found to be synthetic lethal with pfy $1 \Delta$.

genetic screens (Boone et al., 2007). Indeed, the yeast model has proven to be a useful platform for investigating pathogenic mechanisms associated with the ALS disease proteins TDP-43 and FUS (Johnson et al., 2008, 2009; Ju et al., 2011; Sun et al., 2011) and for suggesting novel genetic risk factors for the disease (Elden et al., 2010; Couthouis et al., 2011, 2012). Synthetic lethal and overexpression screens can be used to discover genes and pathways that normally interact with $P F Y 1$ and to identify genetic pathways that can bypass the loss of profilin activity.

We performed an unbiased, genome-wide synthetic lethal screen to identify nonessential yeast gene deletions that became sick or lethal when combined with the PFY1 deletion. We used 
Table 1. Yeast strains synthetically sick or lethal with pfy1s

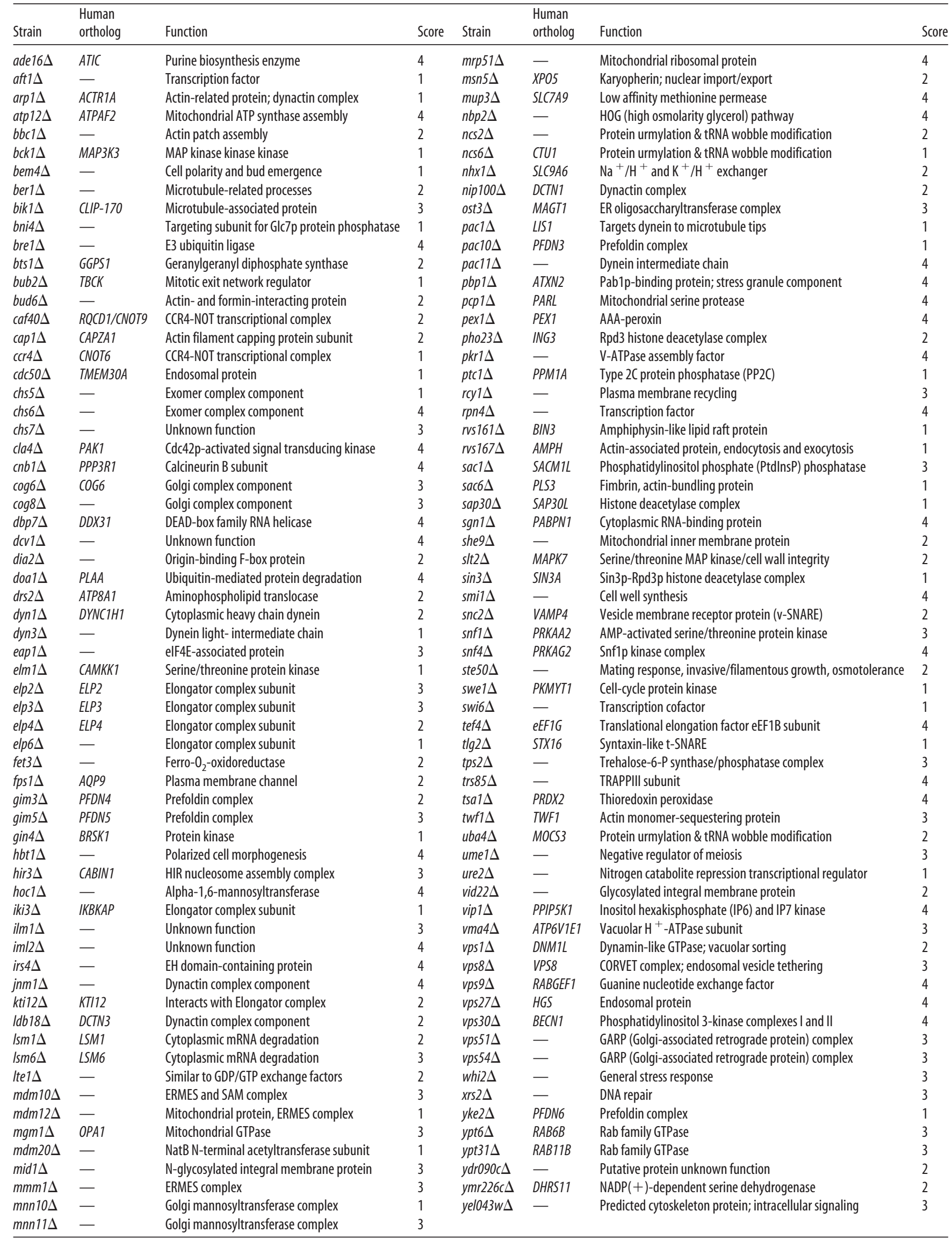

A mean growth score was calculated for each strain and the 127 strains were separated into quartiles ( 1 for strongest lethal interaction, 4 for weakest) to demonstrate their strength of interaction with pfy $1 \Delta$. Human orthologs determined by Protein Basic Local Alignment Search Tool (BLAST) (blast.ncbi.nlm.nih.gov) and functions annotated from the Saccharomyces Genome Database (www.yeastgenome.org). 
A

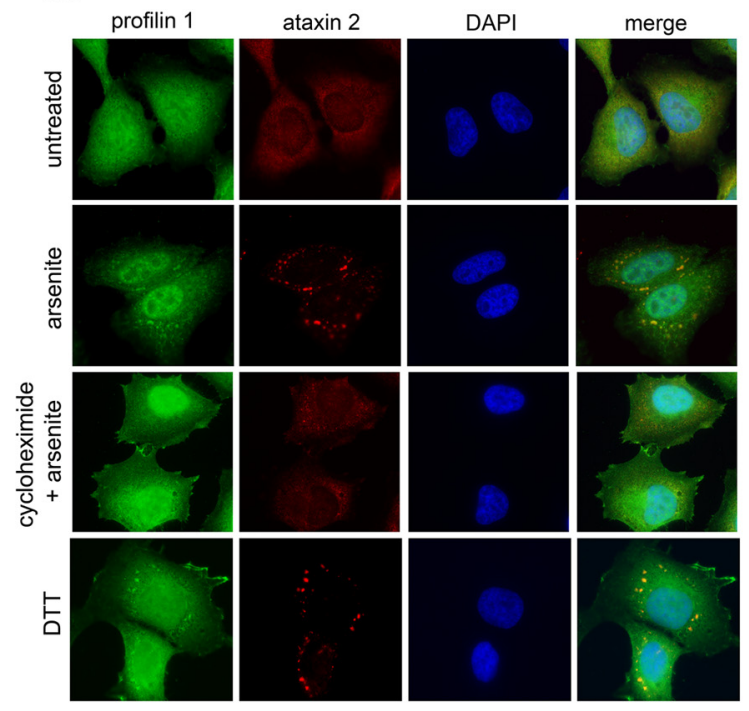

B

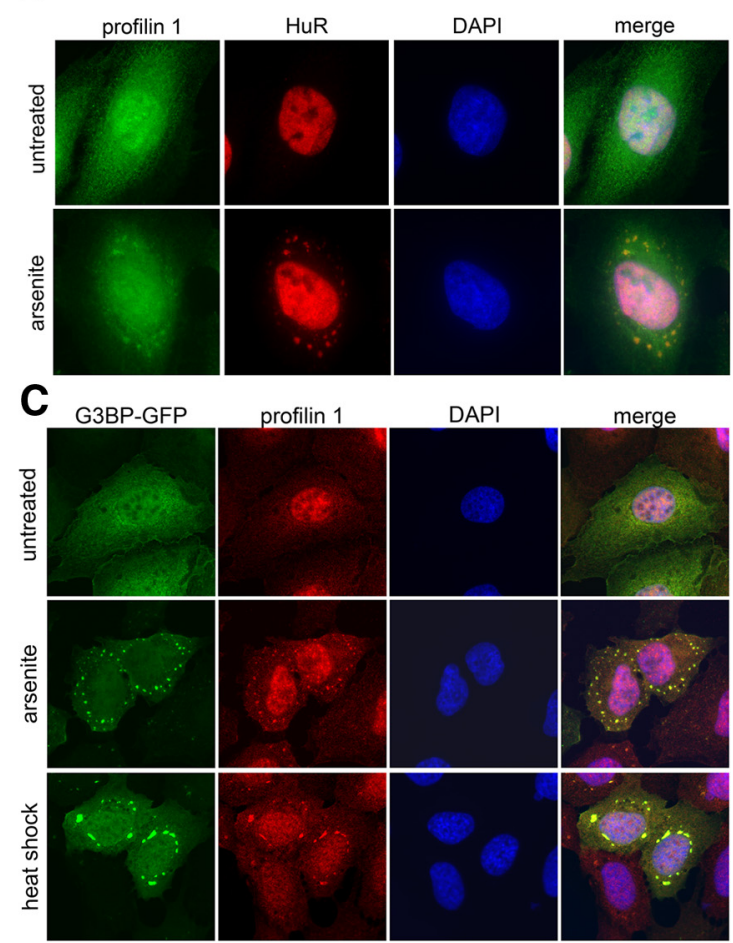

Figure 4. Profilin 1 localizes to stress granules in mammalian cells. $A$, HeLa cells were treated with $0.5 \mathrm{~mm}$ arsenite for $1 \mathrm{~h}$ and coimmunostained with antibodies to detect profilin 1 and ataxin 2. Arsenite treatment resulted in profilin 1 localization to ataxin 2-positive stress granules, whose formation was blocked by cycloheximide treatment. Endoplasmic reticulum stress (2 mm DTT treatment for $1 \mathrm{~h}$ ) also resulted in profilin 1 localization to stress granules. $\boldsymbol{B}$, An independent stress granule marker, HuR, was used to confirm profilin 1 localization to stress granules. C, Profilin 1 also localized to stress granules in U20S cells that express a G3BP-GFP stress granule reporter, upon arsenite or heat shock treatment. Scale bar, $10 \mu \mathrm{m}$.

SGA analysis (Tong et al., 2001) to introduce the $p f y 1 \Delta$ into each nonessential yeast deletion strain by mating (Fig. $3 A$ ). Haploid double deletion mutants were selected and scored based on growth compared with single deletion mutants. We repeated the screen four independent times and only hits that were reproduced at least three of four times were selected for further analysis. We identified 127 gene deletions that were synthetic lethal or synthetic sick in combination with pfy $1 \Delta$ (Fig. $3 B$; Table 1). As expected, because of a well characterized ability of profilin to modulate actin filament dynamics (Wolven et al., 2000), we isolated many actin-associated or actin-regulating genes in the screen, including two previously reported synthetic lethal interactions, bud6 $\Delta$ and $t w f 1 \Delta$ (Wolven et al., 2000; Moseley et al., 2004). Because ALS-linked mutant profilins are deficient in binding actin (Wu et al., 2012), the specific genetic interactors identified here may be useful for future investigation into cytoskeletal defects resulting from PFN1-linked ALS mutations.

Unexpectedly, we identified six of the seven known yeast genes that regulate protein urmylation (GO category 0032447), elp $2 \Delta$, elp $6 \Delta, n c s 2 \Delta, n c s 6 \Delta$, ure $2 \Delta$, and $u b a 4 \Delta$; the final gene a previously identified negative genetic interactor with PFY1 (Surma et al., 2013). Urmylation is a poorly understood ubiquitin-like posttranslational modification in yeast and mammalian cells, potentially involved in nutrient sensing and enhanced by oxidative stress (Goehring et al., 2003; Van der Veen et al., 2011). Two of these genes, ELP2 and ELP6, encode members of the elongator complex (Krogan and Greenblatt, 2001), a sixsubunit holoenzyme component of RNA polymerase II, of which we identified all five nonessential subunits as synthetic lethal with pfy $1 \Delta$ (iki3/elp1 $\Delta$, elp $2 \Delta$, elp $3 \Delta$, elp $4 \Delta$, elp $6 \Delta$ ). Intriguingly, allelic variants in Drosophila ELP3 are important for axonal sur- vival and variants in human ELP3 have been associated with ALS (Simpson et al., 2009). Many of these same genes are also important for tRNA wobble codon modification (GO category 0002098; Fig. 3B) and have recently been implicated as sensitive to changes in cellular actin levels (Haarer et al., 2013). ELP3 also plays a direct role in tubulin acetylation (Creppe et al., 2009), potentially further linking it to the cytoskeleton.

We also found several deletions of yeast genes encoding members of dynein and dynactin complexes to be synthetic lethal with pfy $1 \Delta$ (Table 1). These include dynein heavy chain, $d y n 1 \Delta$, light intermediate chain, $d y n 3 \Delta$, and intermediate chain, pac11 $\Delta$, as well as the dynactin complex genes $\operatorname{arp} 1 \Delta, j n m 1 \Delta, l d b 18 \Delta$, and nip $100 \Delta$. Furthermore, we identified a synthetic lethal interaction of $p f y 1 \Delta$ deletion with two known dynein interactors, pac1 $\Delta$ and $b i k 1 \Delta$, which target dynein to microtubules (Sheeman et al., 2003). Several of these yeast genes have human orthologs (Table $1)$. In yeast these proteins are responsible for spindle assembly and elongation during cell division (Moore et al., 2009), but in postmitotic neurons the dynein and dynactin complexes are essential for the retrograde axonal transport of cargos along microtubules (Goldstein and Yang, 2000). Defects in this pathway have previously been associated with neuronal dysfunction and motor neuron diseases (LaMonte et al., 2002; Puls et al., 2003; Eschbach and Dupuis, 2011; Harms et al., 2012; Ikenaka et al., 2013; Kuźma-Kozakiewicz et al., 2013; Lipka et al., 2013; Oates et al., 2013). Given the enrichment of this pathway in our $p f y 1 \Delta$ synthetic lethal screen, it will be important in future studies to determine whether profilin 1 plays a role in this pathway in neurons and whether ALS-linked mutations in profilin 1 result in defects in dynein-dependent retrograde axonal transport. 

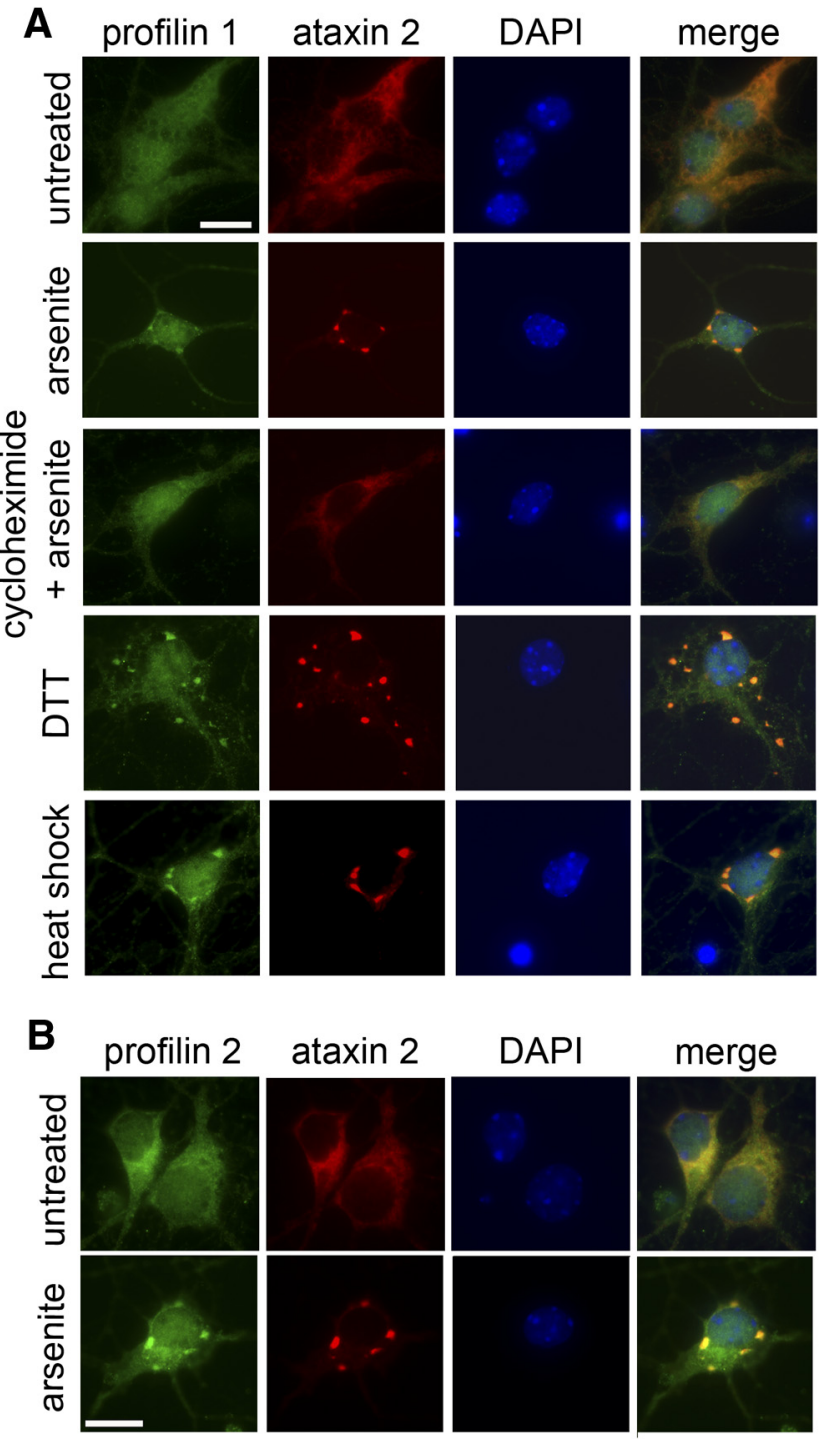

Figure 5. Profilin 1 localizes to stress granules in primary neurons. $A$, Stress granules were induced in primary mouse cortical neurons by treatment with arsenite, DTT, or heat shock. Each of these treatments resulted in profilin 1 localizing to ataxin 2-positive stress granules. Cycloheximide cotreatment was used to block stress granule formation as a specificity control for the profilin 1 stress granule localization. $\boldsymbol{B}$, Profilin 2 also localized to stress granules in primary neurons after $1 \mathrm{~h}$ treatment with arsenite. Scale bar, $10 \mu \mathrm{m}$.

Surprisingly, we identified several genes encoding processing body (P-body) components, stress granule-associated proteins or genes known to modify these granules as strongly interacting with pfy $1 \Delta$ in the synthetic lethal screen (Fig. $3 B$; Table 1). Stress granules and P-bodies are large cytoplasmic RNA-protein assemblies with roles in multiple aspects of RNA metabolism. P-bodies consist chiefly of the RNA decay machinery and are constitutively present, while stress granules form transiently in response to cellular stress and may act as storage sites for translationally repressed mRNA and/or as hubs of stress signaling (Kedersha et al., 2005, 2013; Buchan and Parker, 2009). Notably, lsm $1 \Delta$ and $c c r 4 \Delta$ were synthetic lethal with $p f y 1 \Delta$. They encode two known P-body components (Sheth and Parker, 2003; Reijns et al., 2008). Eap1 $\Delta$, tef $4 \Delta$, and $\operatorname{sgn} 1 \Delta$ were also synthetic lethal with $p f y 1 \Delta$, encoding two known yeast stress-granule associated proteins, eIF4Eassociated protein and $\mathrm{eEF} 1 \mathrm{~B}$, and one likely stress granuleassociated protein, Rbp29 (Buchan et al., 2008; Grousl et al.,
2013; Klass et al., 2013). We also identified several pfy $1 \Delta$ interactors that were also recently recognized in a screen for genes affecting levels of yeast P-bodies and/or stress granules (Buchan et al., 2013), including $b c k 1 \Delta$, gim $5 \Delta$, iki3 $\Delta, l \sin 6 \Delta, m s n 5 \Delta$, and $v m a 4 \Delta$ (Table 1). The results from that screen suggested that the prefoldin complex, a six-subunit molecular chaperone, may be important for yeast P-body granule dynamics (Buchan et al., 2013). Interestingly, four of the seven known members of the prefoldin complex (pac10 $\Delta, y k e 2 \Delta$, gim $3 \Delta$, and gim5 $\Delta$ ) are synthetic lethal with $p f y 1 \Delta$, including gim $3 \Delta$, a previously identified negative genetic interactor with PFY1 (Surma et al., 2013).

Strikingly, we also identified a synthetic lethal interaction between $p f y 1 \Delta$ and $p b p 1 \Delta$. Pbpl is a well established component and modifier of yeast stress granules; deletion of $P B P 1$ results in impaired stress granule formation in yeast (Buchan et al., 2008). $\mathrm{Pbp} 1$ is the yeast ortholog of human ataxin 2 and intermediatelength polyglutamine (polyQ) repeats in ataxin 2 are a genetic risk factor for ALS (Elden et al., 2010). Like Pbp1 in yeast, ataxin 2 is also a stress granule-associated protein in mammalian cells (Ralser et al., 2005). Ataxin 2 levels critically regulate RNP granule formation in mammalian cells-overexpression of ataxin 2 results in a reduction in P-bodies, whereas knockdown of ataxin 2 impairs stress granule formation (Nonhoff et al., 2007).

Impairment of RNP granule dynamics has recently emerged as a central cell biological contributor to ALS pathogenesis (Wolozin, 2012; Buchan et al., 2013; Li et al., 2013; Ramaswami et al., 2013). Several ALS-associated genes including TARDBP, FUS/TLS, VCP, hnRNPA2B1, hnRNPA1, and ATXN2 encode stress granule-interacting proteins. Mutations in these proteins can alter their propensity to transit into and be cleared from stress granules (Bosco et al., 2010; Liu-Yesucevitz et al., 2010; Baron et al., 2013; Buchan et al., 2013; Kim et al., 2013). Several of these same proteins are also known to mislocalize to the proteinaceous inclusions prominent in ALS patient spinal motor neurons (Neumann et al., 2006; Elden et al., 2010; Li et al., 2013). These pathological inclusions in ALS are also immunopositive for other stress granule components such as PABP1, eIF4G, eIF3, ataxin 2, HuR, and TIA-1 (Liu-Yesucevitz et al., 2010; Bentmann et al., 2013). Indeed, it has been suggested that pathological ALS inclusions evolve from persistent stress granules that accumulate as a result of imbalanced assembly and clearance (Ramaswami et al., 2013). Given the accruing evidence for the role of stress granule dynamics in ALS and the enrichment of genes encoding RNPmodifiers and stress granule proteins in our $p f y 1 \Delta$ yeast screen, including $\mathrm{Pbp} 1 /$ ataxin 2, we next tested the hypothesis that profilin 1 associates with stress granules.

\section{Profilin 1 associates with stress granules in human cells}

A role for profilin 1 in stress granules has not been previously reported. We first tested whether profilin 1 could associate with stress granules in human cells. To induce stress granule formation, we treated HeLa cells with $0.5 \mathrm{~mm}$ sodium arsenite (oxidative stress) or 2 mM DTT (endoplasmic reticulum stress) for $1 \mathrm{~h}$. Coimmunostaining for endogenous profilin 1 and ataxin 2, an established stress granule marker, revealed prominent colocalization of profilin 1 with ataxin 2-positive stress granules (Fig. 4A). To verify that these cytoplasmic accumulations represented stress granules, we cotreated cells with cycloheximide, which blocks stress granule formation by inhibiting translation elongation and stopping the release of mRNAs from polysomes (Kedersha and Anderson, 2002). This treatment also blocked profilin 1/ataxin 2-positive stress granule formation (Fig. 4A). We corroborated these findings using a second stress granule marker, the RNA- 
A

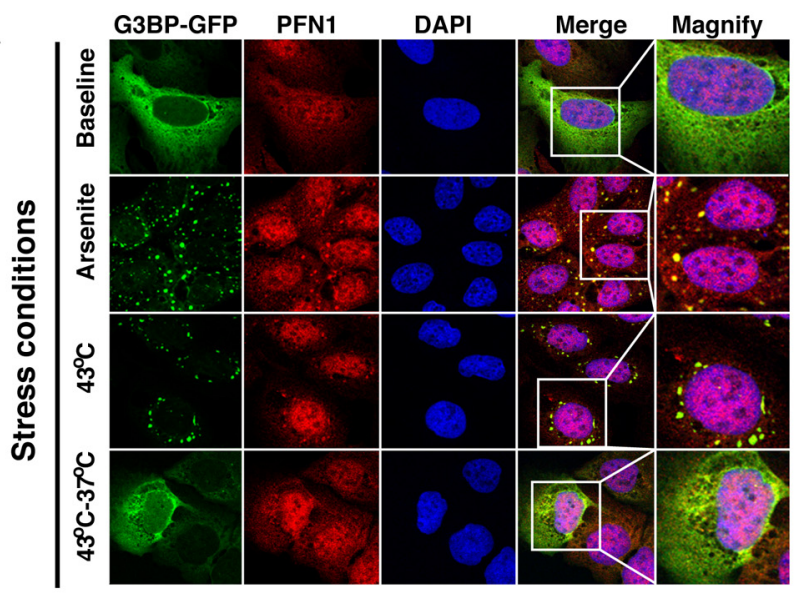

B

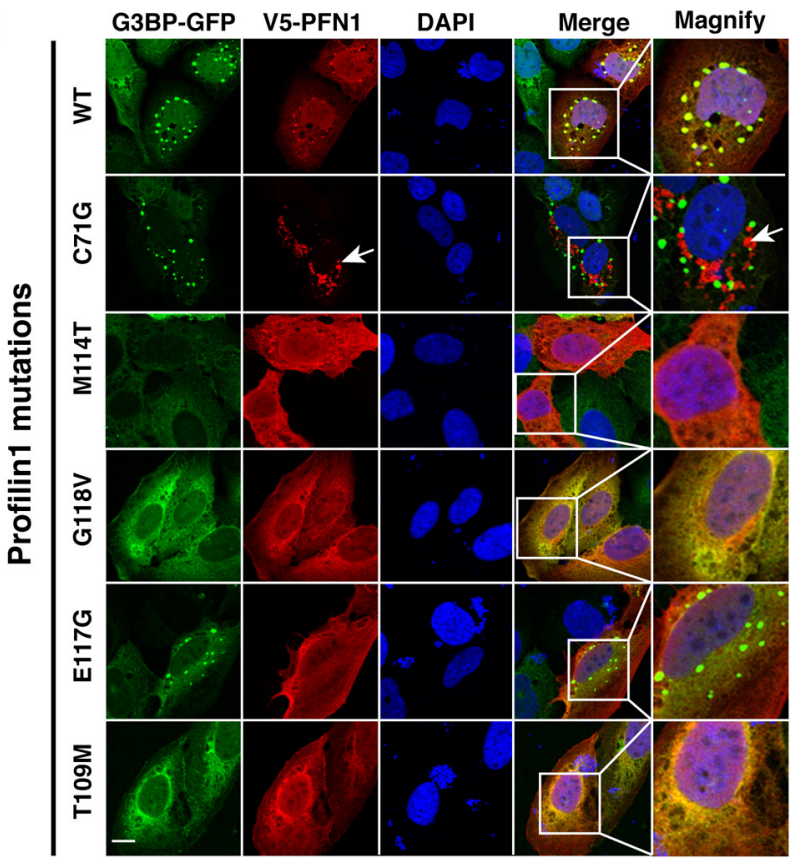

Figure 6. Profilin 1 localizes to stress granules in U20S cells and overexpression can induce stress granule formation in untreated cells. $A$, U20S G3BP-GFP cells stained for endogenous profilin 1 in untreated conditions, after $30 \mathrm{~min} .0 .5 \mathrm{~mm}$ arsenite, $2 \mathrm{~h}$ heat shock at $43^{\circ} \mathrm{C}$, and after $2 \mathrm{~h}$ recovery from the heat shock. $B$, U20S G3BP-GFP cells transiently transfected with V5-WT profilin 1 or ALS-linked mutants. Stably expressed G3BP-GFP was used as a stress granule marker. The arrow points to aggregating C71G-protein separate from G3BP-positive stress granules. Scale bar, $10 \mu \mathrm{m}$.

binding protein $\mathrm{HuR}$. HuR is a predominantly nuclear protein that redistributes into the cytoplasm after arsenite stress (Fig. 4B).

We analyzed profilin 1's association with stress granules in another human cell line. Using osteosarcoma U2OS cells engineered to stably express low levels of the stress granule protein Ras-GAP SH3-domain binding protein tagged to GFP (G3BPGFP), we treated cells for $30 \mathrm{~min}$ with $0.5 \mathrm{~mm}$ sodium arsenite or with a $2 \mathrm{~h}$ heat shock at $43^{\circ} \mathrm{C}$. Both of these treatments induced robust G3BP-GFP-positive stress granule formation. Immunostaining these cells revealed colocalization of endogenous profilin 1 with G3BP-GFP-positive stress granules after arsenite treatment or heat shock (Fig. 4C). Thus, in two independent human cell lines (HeLa and U2OS), using three independent stressors (arsenite, DTT, heat shock), and three independent stress granule markers (ataxin 2, HuR, G3BP), we provide evidence that profilin 1 is a novel stress granule-associated protein.

\section{Profilin 1 and 2 associate with stress granules in primary neurons}

To extend our studies from cell lines to primary neurons, we cultured mouse primary cortical neurons and induced stress granules with a variety of cellular stressors; either $0.5 \mathrm{~mm}$ sodium arsenite, $2 \mathrm{~mm}$ DTT, or heat shock at $43^{\circ} \mathrm{C}$ for $1 \mathrm{~h}$ (Kaehler et al., 2012). Immediately following stress, we fixed the cells and performed immunocytochemistry to determine the localization of profilin 1 and ataxin 2. In untreated mouse primary cortical neurons, as in HeLa and U2OS cells, ataxin 2 and profilin 1 both exhibited a diffuse cytoplasmic signal, with profilin 1 also localizing to the nucleus (Fig. 5A). Ataxin 2 formed stress granules in response to cellular stressors, revealed by immunostaining as several small cytoplasmic puncta (Fig. 5A). Immunostaining for profilin 1 demonstrated prominent colocalization with ataxin 2-positive neuronal stress granules (Fig. 5A). To further test whether these cytoplasmic puncta represent stress granules, we treated neurons with cycloheximide to block the formation of arsenite-induced stress granules (Kedersha and Anderson, 2002). Cotreatment with arsenite and cycloheximide blocked the formation of ataxin 2/profilin 1-positive cytoplasmic puncta, providing further evidence that the profilin 1 puncta represent stress granules.

Neurons are unique among cell types because they express a second profilin protein, profilin 2 (Witke et al., 1998). Given the ability of profilin 2 to compensate for profilin 1 in some aspects of its neuronal functions (Michaelsen et al., 2010) and its ability to rescue $p f y 1 \Delta$ yeast (Fig. $1 D$ ) we also assessed whether profilin 2 could associate with stress granules in mouse primary cortical neurons. We confirmed the specificity of our antibodies to distinguish profilin 1 from profilin 2 using immunoblotting of pfy $1 \Delta$ yeast cells expressing either human profilin 1 or profilin 2 (data not shown) and by immunoblotting following siRNA transfection of the U2OS cells to reduce the expression of profilin 1, profilin 2, or both (data not shown). By immunostaining after $1 \mathrm{~h}$ arsenite treatment, we find that profilin 2 also colocalizes with ataxin 2-positive neuronal stress granules (Fig. 5B). These experiments demonstrate a novel ability of both profilins 1 and 2 to transit to stress granules in mammalian neurons.

\section{ALS-linked PFN1 mutations alter stress granule dynamics}

We next sought to assess whether the ALS-linked mutations in profilin 1 alter its ability to transit to or be cleared from cellular stress granules. We again used the U2OS-G3BP-GFP cells to monitor stress granule dynamics. Nearly all cells form robust G3BP and profilin 1-positive stress granules after 30 min treatment with $0.5 \mathrm{~mm}$ arsenite or $2 \mathrm{~h}$ heat shock at $43^{\circ} \mathrm{C}$, and stress granules dissolve in $\sim 90 \%$ of cells allowed to recover for a further $2 \mathrm{~h}$ at $37^{\circ} \mathrm{C}$ (Figs. $6 A, 7 D$; quantification as "endogenous"). We then compared stress granule dynamics in these cells after transient transfection with plasmids encoding N-terminally V5tagged WT profilin 1 or the ALS-linked profilin 1 mutants C71G, T109M, M114T, E117G, and G118V. We chose the relatively small V5-tag at the $\mathrm{N}$ terminus given the small size of profilin 1 $(\sim 15 \mathrm{kDa})$ and previous studies establishing the damaging effects of tagging profilin with a large fluorescent protein like GFP at the C-terminus (Wittenmayer et al., 2000). We fixed cells and performed immunocytochemistry to detect profilin 1's V5 epitope tag. Transient transfection of WT profilin 1 was sufficient to induce stress granules in $18.6 \%$ of cells in the absence of stress (Figs. 
A
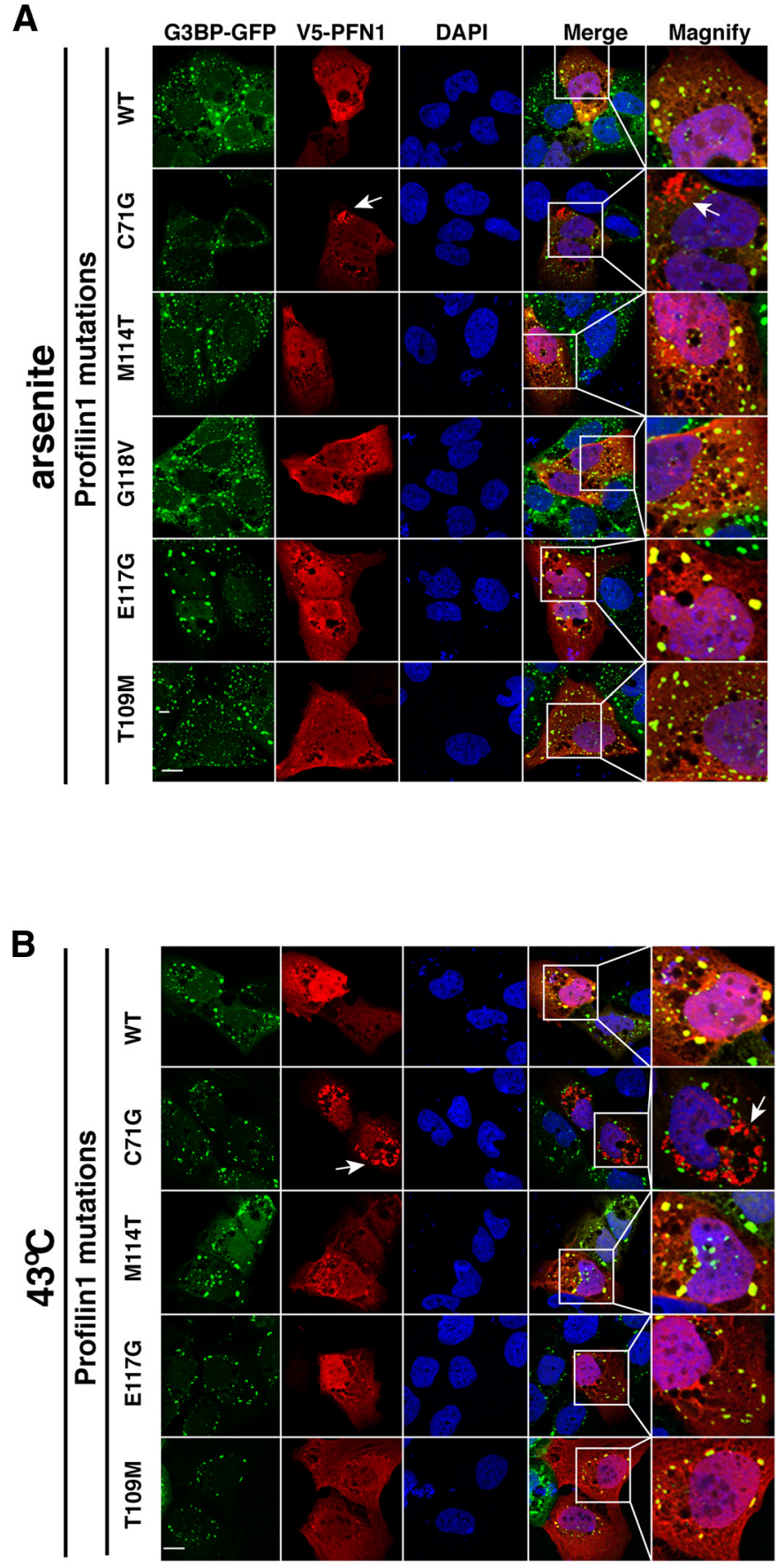

C

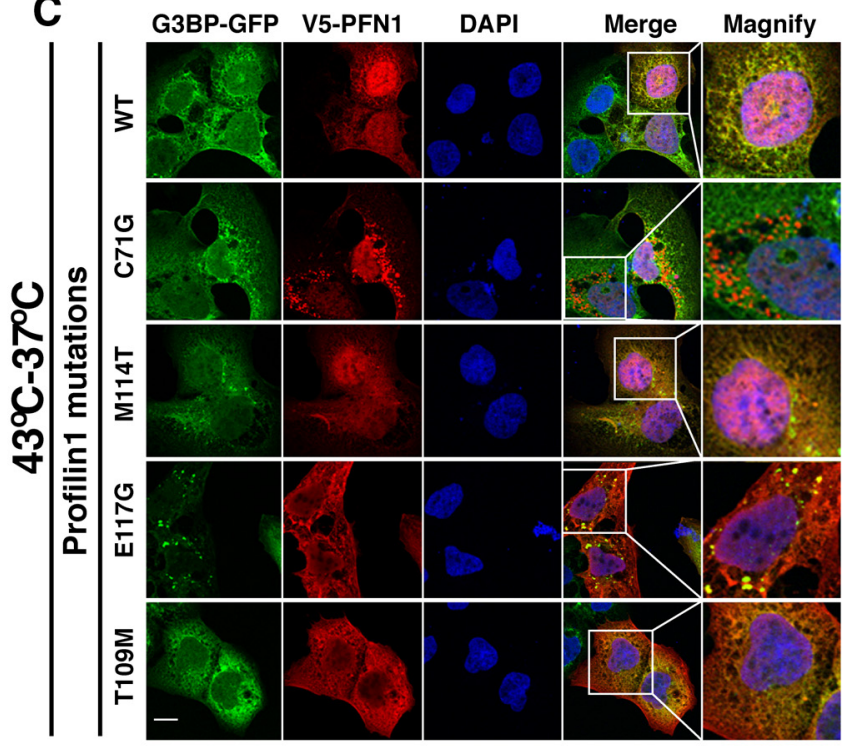

D

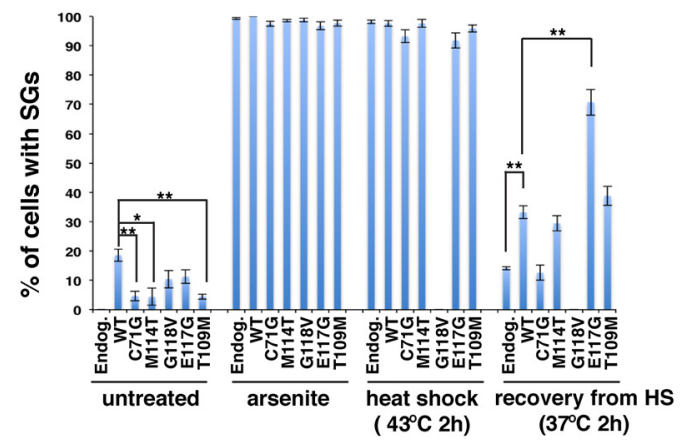

E

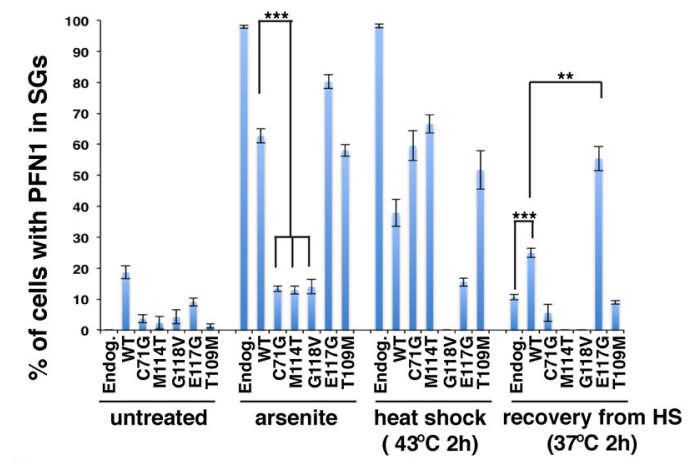

$\mathbf{F}$

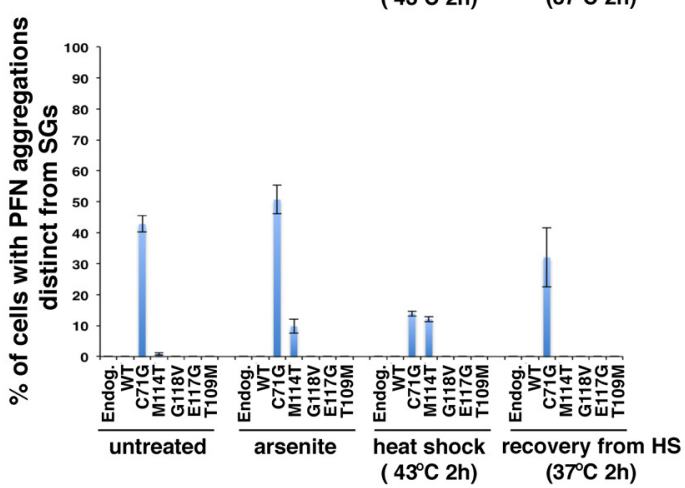

Figure 7. Effect of profilin 1 and ALS-linked mutations on stress granule dynamics. $A$, U2OS G3BP-GFP cells transiently transfected with V5-WT profilin 1 or ALS-linked mutations and treated with $0.5 \mathrm{~mm}$ arsenite for $30 \mathrm{~min} ; \boldsymbol{B}, 2 \mathrm{~h}$ heat shock at $43^{\circ} \mathrm{C}$; and $\boldsymbol{C}$, after $2 \mathrm{~h}$ recovery from the heat shock. Arrows point to aggregating $C 71 \mathrm{G}$-protein separate from $G 3 B \mathrm{BP}$-positive stress granules. $\boldsymbol{D}, \boldsymbol{E}, \boldsymbol{F}$, Quantification of data in Figures $6\left(A\right.$, endogenous; $B$, transfected but untreated) and $7 A-C$. Mean values based on a minimum of three replicate experiments $\pm S E M ;{ }^{*} p=<0.05,{ }^{* *} p=<0.01$, $\left.{ }^{* * *} p=<0.001\right)$. Scale bar, $10 \mu \mathrm{m}$. 
A

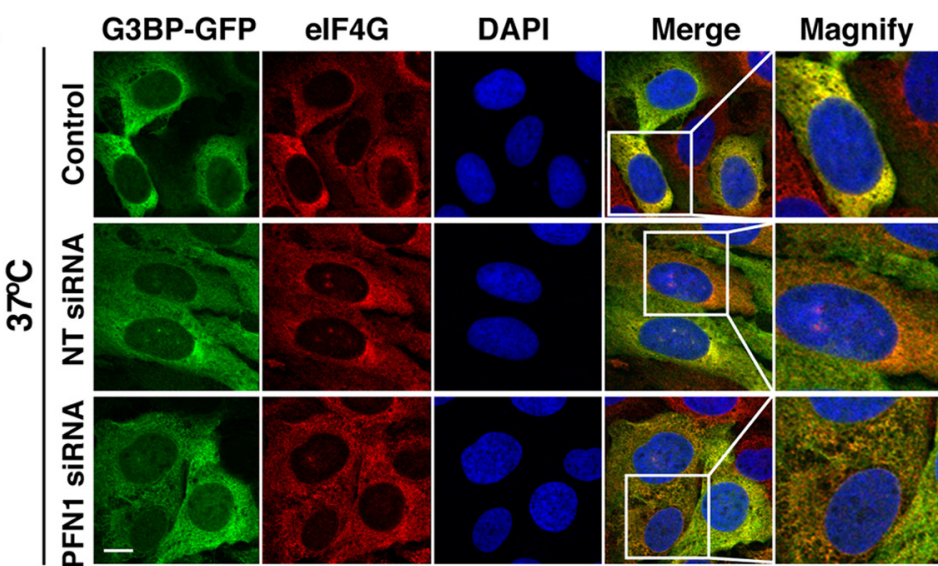

옹

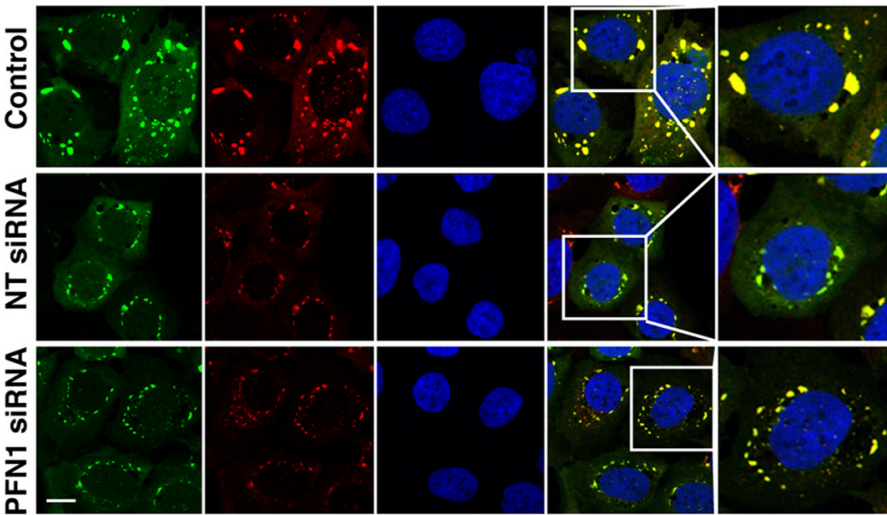

ชิ|

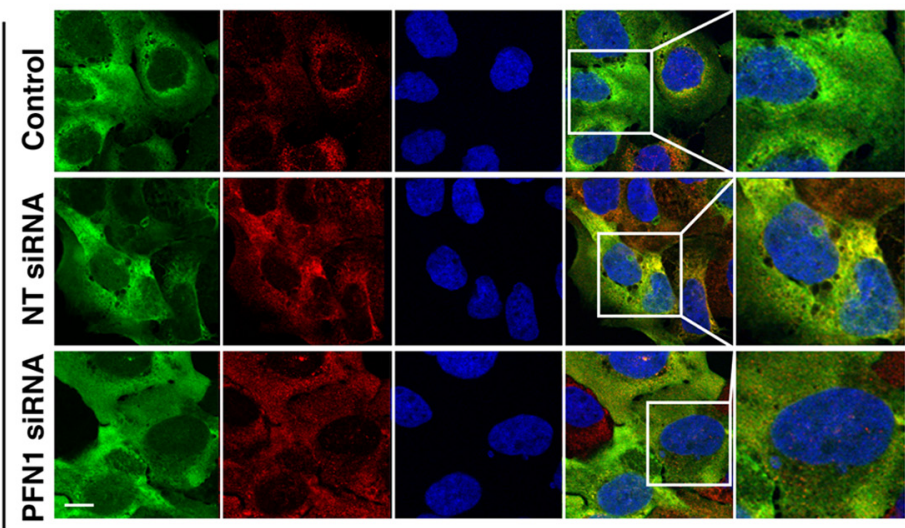

B

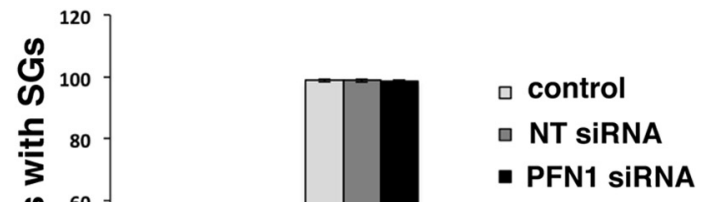

C

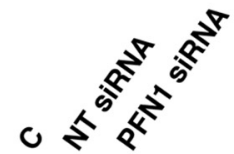

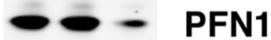

$\sim-$ actin

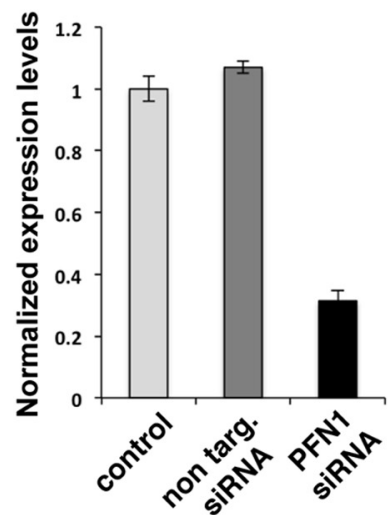

Figure 8. Profilin 1 is not required for stress granule assembly or disassembly in human U2OS cells. A, U20S-G3BP-GFP cells examined by immunofluorescence for the stress granule markers G3BP and elF4G. Cells show stress granule assembly upon heat shock at $43^{\circ} \mathrm{C}(2 \mathrm{~h})$ and rapid clearance of stress granules upon return to $37^{\circ} \mathrm{C}$. Cells treated with PFN1-targeting siRNA or with control nontargeting siRNA show normal stress granule assembly, and normal disassembly following return to $37^{\circ} \mathrm{C}(2 \mathrm{~h})$. Scale bar, $10 \mu \mathrm{m} . B$, Quantification of data in $A$, mean values based on a minimum of three replicate experiments \pm SEM. C, Western blot and quantification of PFN1 protein levels in cells from $A$, mean values based on a minimum of three replicate experiments \pm SEM.

$6 B, 7 D, E)$. This suggests that profilin 1 may promote stress granule assembly, a function previously attributed to other stress granule-associated proteins, including G3BP and TIA-1 (Tourrière et al., 2003; Gilks et al., 2004). Compared with the WT profilin 1 protein, the C71G, M114T, and T109M mutants were impaired in their ability to induce stress granules in untreated cells, suggesting a loss-of-function (Figs. 6B, 7D; WT vs C71G, M114T, and T109M, $p=4.4 \mathrm{E}-3,0.016$, and 5.4E-3, respectively). Strikingly, the C71G mutation, and to a lesser extent the M114T mutation, resulted in cytoplasmic protein aggregates distinct from stress granules (Fig. 6B), consistent with previous observations in other cell types (Wu et al., 2012). These cytoplasmic protein aggregations, which are distinct from stress granules, are observed in untreated cells and persist during arsenite and heat shock treatment and after recovery (Fig. $7 A-C, F$ ).

After arsenite or heat shock, V5-tagged WT profilin 1 localized to G3BP-GFP-positive stress granules (Fig. $7 \mathrm{~A}, \mathrm{~B}$ ), providing further confirmation that profilin 1 localizes to stress granules. After $30 \mathrm{~min}$ arsenite treatment or $2 \mathrm{~h} 43^{\circ} \mathrm{C}$ heat shock, all cells formed G3BP-GFP-positive stress granules regardless of the presence of WT profilin 1 or the ALS-linked mutant proteins (Figs. $6 B, 7 A-D)$. Thus, the presence of ALS-linked profilin 1 mutant proteins does not affect stress granule formation per se. The one exception to this rule was the G118V mutant, which resulted in cell death upon heat shock stress (Fig. 7D). This behavior suggests a gain-of-function and/or dominant negative toxicity for overex- 


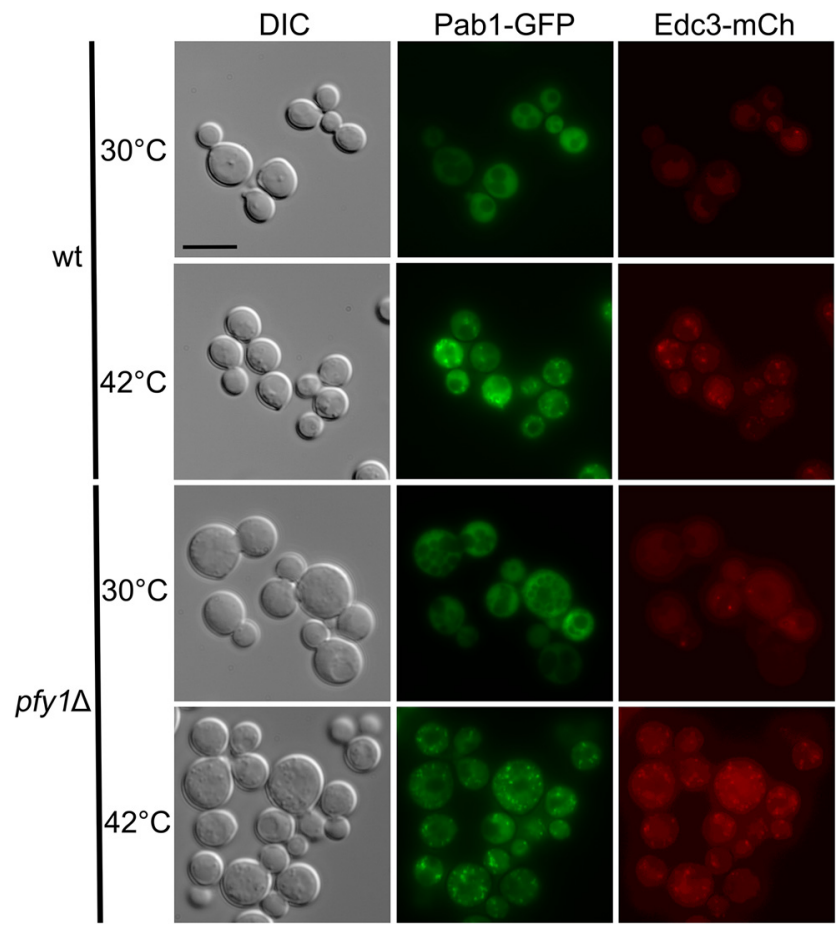

Figure 9. Profilin is not required for stress granule assembly after heat shock in yeast. WT and pfy $1 \Delta$ yeast expressing Pab1-GFP as a stress granule marker and Edc3-mCherry as a P-body marker were grown to mid-log phase and then subjected to $15 \mathrm{~min}$ at $30^{\circ} \mathrm{C}$ or heat shock at $42^{\circ} \mathrm{C}$. Live cells were imaged using a fluorescence microscope. Scale bar, $7 \mu \mathrm{m}$.

pression of the profilin $1 \mathrm{G} 118 \mathrm{~V}$ mutant protein during cellular stress. Although the other ALS-linked profilin 1 mutations did not affect the ability of the cells to form stress granules (Fig. $7 A-D$ ), the C71G, M114T, and G118V mutants were themselves defective at being targeted to those arsenite-induced stress granules compared with WT profilin 1 (Fig. 7 D, E; WT vs C71G, M114T, and G118V, $p=7.8 \mathrm{E}-4,1.9 \mathrm{E}-5$, and 1.2E-5, respectively).

Paralleling the transient expression of WT profilin 1 inducing stress granule formation in untreated cells, expression of the WT protein also resulted in a marked decrease in the ability of stress granules to be cleared after recovery from heat shock (Fig. 7C-E; endogenous vs WT, $p=3.3 \mathrm{E}-3$ ). Expression of the E117G variant protein caused an even greater reduction in the ability of the cell to disassemble stress granules after recovery (Fig. 7C-E; WT vs E117G, $p=2 \mathrm{E}-3$ ), potentially providing a mechanism for E117G as an ALS risk factor (Fratta et al., 2014).

\section{Profilin 1 is not required for stress granule formation in human U2OS cells or in yeast}

Because overexpression of WT profilin 1 can induce stress granule formation (Fig. 6A), we next sought to assess whether profilin 1 is required for stress granule formation or clearance. We reduced profilin 1 levels in U2OS G3BP-GFP cells by treatment with an siRNA pool targeting profilin 1 . As controls, cells were left untreated or were treated with nontargeting siRNAs. After $48 \mathrm{~h}$ treatment with siRNA, cells were left at $37^{\circ} \mathrm{C}$, were subjected to $43^{\circ} \mathrm{C}$ heat shock for $2 \mathrm{~h}$ to induce stress granule formation, or $2 \mathrm{~h}$ heat shock and $2 \mathrm{~h}$ recovery at $37^{\circ} \mathrm{C}$ to monitor stress granule disassembly, followed by fixation. Cells with stress granules were quantified using fluorescence microscopy to detect G3BP-GFP and immunostaining for endogenous eIF4G as an independent stress granule marker (Fig. 8A). Reducing profilin 1 levels by $\sim 70 \%$ (Fig. $8 C$ ), we observed no change in stress granule forma- tion in response to heat shock or in stress granule clearance following heat shock recovery (Fig. $8 B$ ), suggesting that profilin 1 is not essential to these processes.

We performed similar loss-of-function studies to determine whether profilin is required for stress granule formation in yeast. We transformed WT or $p f y 1 \Delta$ yeast cells with a plasmid encoding Pab1-GFP as a stress granule marker and Edc3-mCherry as a P-body marker. Yeast were grown to mid-log phase and stress granules were induced by $15 \mathrm{~min}$. heat shock at $42^{\circ} \mathrm{C}$. Both WT and $p f y 1 \Delta$ yeast cells responded to heat shock by forming robust Pab1-GFP stress granules, as well as inducing an increase in Edc3mCherry-positive P-bodies (Fig. 9), suggesting that the yeast profilin, similar to human profilin 1 , is not required for stress granule formation in response to heat shock stress.

\section{Discussion}

Mutations in the PFN1 gene were recently identified as a cause of FALS (Wu et al., 2012). We developed a simple yeast model system to test the effects of the ALS-linked variants on profilin 1 function. Whereas WT profilin 1 could functionally replace yeast profilin, several of the ALS-linked variants, including C71G, M114T, and G118V were defective in this function. Our yeast data suggest that the E1 $17 \mathrm{G}$ variant is unlikely to be pathogenic or is incompletely penetrant, consistent with it being identified in both ALS cases and controls (Wu et al., 2012). We suggest that this yeast model will be a useful platform for rapidly testing the effects of any new PFN1 variant identified by additional sequencing of ALS cases and controls.

Another use for the yeast model could be to compare and contrast the severity of profilin 1 variants to prioritize them for generating additional model systems, such as fly, worm, zebrafish, and mouse. Based on our analysis of the existing ALSlinked profilin 1 variants in yeast as well as the results of Landers and colleagues (Wu et al., 2012), the C71G variant might be the best variant to pursue in such studies.

Given the strong functional conservation between yeast and human profilin 1 (Fig. 1A), we performed an unbiased genetic screen in yeast to elucidate novel functions for yeast profilin as well as new regulators of its known functions. We identified three main classes of genes: (1) genes involved in actin binding and cytoskeletal dynamics, (2) dynein and dynactin associated genes, and (3) genes involved in stress granules and P-bodies. Because of the emergence of stress granules as key contributors to ALS pathogenesis (Li et al., 2013), we focused our studies on potential roles of profilin 1 in stress granules.

Using multiple independent mammalian cell lines, including primary rodent neurons, we provide evidence that profilin 1 (and profilin 2) robustly localizes to stress granules upon exposure to diverse environmental stressors. These results now link profilin 1, the newest ALS disease protein, to stress granules, and raise the question of how profilin 1 associates with stress granules and what effect the ALS-linked profilin 1 mutations have on stress granule localization and/or dynamics.

Using a stress granule reporter cell line (U2OS-G3BP-GFP) we quantitatively assessed stress granule assembly and disassembly and tested the effects of WT and ALS-linked profilin 1 mutations on this process. Transient transfection of WT profilin 1 induced stress granule formation and delayed disassembly following stress, suggesting that profilin 1 activity promotes stress granule assembly. Interestingly, the profilin 1 mutants $\mathrm{C} 71 \mathrm{G}$, $\mathrm{M} 114 \mathrm{~T}$, and T109M were impaired in the ability to induce stress granule formation in the absence of stress. Expression of one of the ALS-linked profilin 1 mutants, G118V, caused cell death fol- 
lowing heat stress. Whereas the other ALS-linked profilin $1 \mathrm{mu}-$ tants did not disrupt the ability of cells to form stress granules, the C71G, M114T, and G118V mutant proteins were defective at being targeting to arsenite-induced stress granules when compared with the WT protein, and the E117G mutant was significantly slower to be cleared from stress granules upon heat stress removal. Two of these profilin 1 mutants, C71G and M114T, also formed aggregates that were distinct from stress granules. In summary, these experiments demonstrate that ALS-linked mutations in profilin 1 can alter the ability of the protein to be targeted to and cleared from cellular stress granules. Thus, profilin 1 can be added to the growing list of ALS-linked mutations in several genes, including TARDBP, FUS/TLS, hnRNPAl, hn$R N P A 2 / B 1$, and $V C P$, which result in mutant proteins with altered stress granule dynamics (Liu-Yesucevitz et al., 2010; Baron et al., 2013; Buchan et al., 2013; Kim et al., 2013). Future studies will be required to define the mechanism by which profilin 1 is recruited to stress granules (i.e., is actin binding required?). Our studies reveal an unexpected and highly conserved connection between profilin 1 and cellular stress granules and provide mechanistic insight into how ALS-linked mutations can affect stress granule dynamics.

The identification of profilin 1 mutations as a cause of FALS opens up a new area of ALS research and suggests that defects in actin dynamics and the cytoskeleton might contribute to pathogenesis. These core cell biological processes are remarkably well conserved, making yeast an ideal model system for studying profilin biology and a launching pad for follow-up experiments in more complicated model systems. Our yeast screens also reveal unexpected connections to dynein/dynactin complexes and stress granules, both of which can be pursued further in yeast and other model systems. Intriguingly, dynein has been previously implicated as a regulator of stress granule dynamics in mammalian and Drosophila-derived cells. Dynein light, intermediate, and heavy chains, as well as the dynein adaptor bicaudal D1 (BicD1) have been localized to stress granules (Loschi et al., 2009; Tsai et al., 2009). Furthermore, stress granule formation is severely impaired by inhibiting dynein function, either by RNAi knockdown of dynein components or overexpression of dominant negative p50 dynactin (Loschi et al., 2009; Tsai et al., 2009).

Although profilin has a well characterized role in modulating actin filaments, the genetic interaction between profilin and dynein/dynactin makes it tempting to speculate that the former might also intersect with microtubule-based processes. The surprising finding that the microtubule subunit tubulin forms a complex with profilin 1 in mouse brain lysates (Witke et al., 1998) also fuels this speculation. While several studies using microtubule-altering manipulations point to a role for the microtubule cytoskeleton in stress granule dynamics (Ivanov et al., 2003; Kwon et al., 2007; Kolobova et al., 2009; Loschi et al., 2009), a defining role of the filamentous actin cytoskeleton in this process remains unresolved. Initial studies using actin filament destabilizing drugs have reported various changes in stress granule dynamics, including an increase in the proportion of large stress granules (latrunculin B; Ivanov et al., 2003), the formation of scattered, numerous small granules (cytochalasin B; Loschi et al., 2009), or no change in stress granule formation (latrunculin B or cytochalasin D; Kwon et al., 2007). Stress granule formation and disassembly are also blocked by pharmacologic treatment of cells with the dynein inhibitor EHNA, a result that has been interpreted as evidence of a role for dynein and microtubules in stress granule dynamics (Kwon et al., 2007; Tsai et al., 2009). However, EHNA treatment is not entirely selective toward dynein motor inhibition, but also severely impairs several actin-dependent processes, including actin filament formation (Schliwa et al., 1984). Importantly, the actin and microtubule cytoskeletons can be functionally linked (Ji et al., 2002). This has been observed in the Drosophila oocyte, as microtubule bundling and microtubuledependent cytoplasmic streaming are induced by actin filament disruption with cytochalasin D treatment and in Drosophila profilin 1 chickadee mutants (Manseau et al., 1996). Given our finding of profilins 1 and 2 as stress granule-associated proteins, the role of the actin and microtubule cytoskeletons in stress granule dynamics clearly deserves further attention.

Our studies revealed an unexpected genetic interaction between profilin 1 and ataxin 2, which led us to pursue a role for profilin 1 in stress granules. Another possible interpretation of these results is that ataxin 2 might play an important role in actin-regulated cellular processes and cytoskeletal dynamics. Intriguingly, in Drosophila, either loss or upreglation of the ataxin 2 ortholog Datx2 causes germline and sensory bristle defects nearly identical to those of the Drosophila profilin 1 mutant chickadee (Satterfield et al., 2002). Yeast ataxin 2 ortholog Pbp1 has also been localized to cortical actin patches (Michelot et al., 2010). These results, together with our identification of a synthetic lethal interaction between $P B P 1$ and $P F Y 1$ in yeast, suggest that ataxin 2 may function in parallel to or regulate profilin 1's role in the assembly and bundling of actin filaments. Future studies will focus on defining the interplay between profilin 1 , ataxin 2 , actin dynamics, stress granules, and ALS pathogenesis.

\section{References}

Alberti S, Gitler AD, Lindquist S (2007) A suite of gateway cloning vectors for high-throughput genetic analysis in Saccharomyces cerevisiae. Yeast 24:913-919. CrossRef Medline

Armakola M, Higgins MJ, Figley MD, Barmada SJ, Scarborough EA, Diaz Z, Fang X, Shorter J, Krogan NJ, Finkbeiner S, Farese RV Jr, Gitler AD (2012) Inhibition of RNA lariat debranching enzyme suppresses TDP-43 toxicity in ALS disease models. Nat Genet 44:1302-1309. CrossRef Medline

Barmada SJ, Skibinski G, Korb E, Rao EJ, Wu JY, Finkbeiner S (2010) Cytoplasmic mislocalization of TDP-43 is toxic to neurons and enhanced by a mutation associated with familial amyotrophic lateral sclerosis. J Neurosci 30:639-649. CrossRef Medline

Baron DM, Kaushansky LJ, Ward CL, Sama RR, Chian RJ, Boggio KJ, Quaresma AJ, Nickerson JA, Bosco DA (2013) Amyotrophic lateral sclerosis-linked FUS/TLS alters stress granule assembly and dynamics. Mol Neurodegener 8:30. CrossRef Medline

Bentmann E, Haass C, Dormann D (2013) Stress granules in neurodegeneration-lessons learnt from TAR DNA binding protein of $43 \mathrm{kDa}$ and fused in sarcoma. FEBS J 280:4348-4370. CrossRef Medline

Boone C, Bussey H, Andrews BJ (2007) Exploring genetic interactions and networks with yeast. Nat Rev Genet 8:437-449. CrossRef Medline

Bosco DA, Lemay N, Ko HK, Zhou H, Burke C, Kwiatkowski TJ Jr, Sapp P, McKenna-Yasek D, Brown RH Jr, Hayward LJ (2010) Mutant FUS proteins that cause amyotrophic lateral sclerosis incorporate into stress granules. Hum Mol Genet 19:4160-4175. CrossRef Medline

Bruijn LI, Houseweart MK, Kato S, Anderson KL, Anderson SD, Ohama E, Reaume AG, Scott RW, Cleveland DW (1998) Aggregation and motor neuron toxicity of an ALS-linked SOD1 mutant independent from wildtype SOD1. Science 281:1851-1854. CrossRef Medline

Buchan JR, Parker R (2009) Eukaryotic stress granules: the ins and outs of translation. Mol Cell 36:932-941. CrossRef Medline

Buchan JR, Muhlrad D, Parker R (2008) P bodies promote stress granule assembly in Saccharomyces cerevisiae. J Cell Biol 183:441-455. CrossRef Medline

Buchan JR, Nissan T, Parker R (2010) Analyzing P-bodies and stress granules in Saccharomyces cerevisiae. Meth Enzymol 470:619-640. CrossRef Medline

Buchan JR, Kolaitis RM, Taylor JP, Parker R (2013) Eukaryotic stress gran- 
ules are cleared by autophagy and Cdc48/VCP function. Cell 153:14611474. CrossRef Medline

Chen Y, Zheng ZZ, Huang R, Chen K, Song W, Zhao B, Chen X, Yang Y, Yuan L, Shang HF (2013) PFN1 mutations are rare in Han Chinese populations with amyotrophic lateral sclerosis. Neurobiol Aging 34:1922.e11922.e5. CrossRef Medline

Cleveland DW, Rothstein JD (2001) From Charcot to Lou Gehrig: deciphering selective motor neuron death in ALS. Nat Rev Neurosci 2:806819. CrossRef Medline

Collins SR, Schuldiner M, Krogan NJ, Weissman JS (2006) A strategy for extracting and analyzing large-scale quantitative epistatic interaction data. Genome Biol 7:R63. CrossRef Medline

Cooper AA, Gitler AD, Cashikar A, Haynes CM, Hill KJ, Bhullar B, Liu K, Xu K, Strathearn KE, Liu F, Cao S, Caldwell KA, Caldwell GA, Marsischky G, Kolodner RD, Labaer J, Rochet JC, Bonini NM, Lindquist S (2006) Alpha-synuclein blocks ER-Golgi traffic and Rab1 rescues neuron loss in Parkinson's models. Science 313:324-328. CrossRef Medline

Couthouis J, Hart MP, Shorter J, DeJesus-Hernandez M, Erion R, Oristano R, Liu AX, Ramos D, Jethava N, Hosangadi D, Epstein J, Chiang A, Diaz Z, Nakaya T, Ibrahim F, Kim HJ, Solski JA, Williams KL, MojsilovicPetrovic J, Ingre C, et al. (2011) A yeast functional screen predicts new candidate ALS disease genes. Proc Natl Acad Sci U S A 108:20881-20890. CrossRef Medline

Couthouis J, Hart MP, Erion R, King OD, Diaz Z, Nakaya T, Ibrahim F, Kim HJ, Mojsilovic-Petrovic J, Panossian S, Kim CE, Frackelton EC, Solski JA, Williams KL, Clay-Falcone D, Elman L, McCluskey L, Greene R, Hakonarson H, Kalb RG, et al. (2012) Evaluating the role of the FUS/TLSrelated gene EWSR1 in amyotrophic lateral sclerosis. Hum Mol Genet 21:2899-2911. CrossRef Medline

Creppe C, Malinouskaya L, Volvert ML, Gillard M, Close P, Malaise O, Laguesse S, Cornez I, Rahmouni S, Ormenese S, Belachew S, Malgrange B, Chapelle JP, Siebenlist U, Moonen G, Chariot A, Nguyen L (2009) Elongator controls the migration and differentiation of cortical neurons through acetylation of alpha-tubulin. Cell 136:551-564. CrossRef Medline

Daoud H, Dobrzeniecka S, Camu W, Meininger V, Dupré N, Dion PA, Rouleau GA (2013) Mutation analysis of PFN1 in familial amyotrophic lateral sclerosis patients. Neurobiol Aging 34:1311.e1-1311.e2. CrossRef Medline

Dillen L, Van Langenhove T, Engelborghs S, Vandenbulcke M, Sarafov S, Tournev I, Merlin C, Cras P, Vandenberghe R, De Deyn PP, Jordanova A, Cruts M, Van Broeckhoven C, van der Zee J, BELNEU Consortium (2013) Explorative genetic study of UBQLN2 and PFN1 in an extended Flanders-Belgian cohort of frontotemporal lobar degeneration patients. Neurobiol Aging 34:1711.e1-1711.e5. CrossRef Medline

Elden AC, Kim HJ, Hart MP, Chen-Plotkin AS, Johnson BS, Fang X, Armakola M, Geser F, Greene R, Lu MM, Padmanabhan A, Clay-Falcone D, McCluskey L, Elman L, Juhr D, Gruber PJ, Rüb U, Auburger G, Trojanowski JQ, Lee VM, et al. (2010) Ataxin-2 intermediate-length polyglutamine expansions are associated with increased risk for ALS. Nature 466:1069-1075. CrossRef Medline

Eschbach J, Dupuis L (2011) Cytoplasmic dynein in neurodegeneration. Pharmacol Ther 130:348-363. CrossRef Medline

Fratta P, Charnock J, Collins T, Devoy A, Howard R, Malaspina A, Orrell R, Sidle K, Clarke J, Shoai M, Lu CH, Hardy J, Plagnol V, Fisher EM (2014) Profilin1 E117G is a moderate risk factor for amyotrophic lateral sclerosis. J Neurol Neurosurg Psychiatry 85:506-508. CrossRef Medline

Gietz D, St Jean A, Woods RA, Schiestl RH (1992) Improved method for high efficiency transformation of intact yeast cells. Nucleic Acids Res 20:1425. CrossRef Medline

Gilks N, Kedersha N, Ayodele M, Shen L, Stoecklin G, Dember LM, Anderson P (2004) Stress granule assembly is mediated by prion-like aggregation of TIA-1. Mol Biol Cell 15:5383-5398. CrossRef Medline

Gitler AD (2008) Beer and bread to brains and beyond: can yeast cells teach us about neurodegenerative disease? Neurosignals 16:52-62. CrossRef Medline

Gitler AD, Chesi A, Geddie ML, Strathearn KE, Hamamichi S, Hill KJ, Caldwell KA, Caldwell GA, Cooper AA, Rochet JC, Lindquist SL (2009) $\alpha$-Synuclein is part of a diverse and highly conserved interaction network that includes PARK9 and manganese toxicity. Nat Genet 41:308-315. CrossRef Medline

Goehring AS, Rivers DM, Sprague GF Jr (2003) Urmylation: a ubiquitin- like pathway that functions during invasive growth and budding in yeast. Mol Biol Cell 14:4329-4341. CrossRef Medline

Goldstein LS, Yang Z (2000) Microtubule-based transport systems in neurons: the roles of kinesins and dyneins. Annu Rev Neurosci 23:39-71. CrossRef Medline

Grousl T, Ivanov P, Malcová I, Pompach P, Frýdlová I, Slaba R, Senohrabkova L, Nováková L, Hasek J (2013) Heat shock-induced accumulation of translation elongation and termination factors precedes assembly of stress granules in S. cerevisiae. PLoS ONE 8:e57083. CrossRef Medline

Haarer B, Mi-Mi L, Cho J, Cortese M, Viggiano S, Burke D, Amberg D (2013) Actin dosage lethality screening in yeast mediated by selective ploidy ablation reveals links to urmylation/wobble codon recognition and chromosome stability. G3 3:553-561. CrossRef Medline

Harms MB, Ori-McKenney KM, Scoto M, Tuck EP, Bell S, Ma D, Masi S, Allred P, Al-Lozi M, Reilly MM, Miller LJ, Jani-Acsadi A, Pestronk A, Shy ME, Muntoni F, Vallee RB, Baloh RH (2012) Mutations in the tail domain of DYNC1H1 cause dominant spinal muscular atrophy. Neurology 78:1714-1720. CrossRef Medline

Ikenaka K, Kawai K, Katsuno M, Huang Z, Jiang YM, Iguchi Y, Kobayashi K, Kimata T, Waza M, Tanaka F, Mori I, Sobue G (2013) Dnc-1/dynactin 1 knockdown disrupts transport of autophagosomes and induces motor neuron degeneration. PLoS ONE 8:e54511. CrossRef Medline

Ingre C, Landers JE, Rizik N, Volk AE, Akimoto C, Birve A, Hübers A, Keagle PJ, Piotrowska K, Press R, Andersen PM, Ludolph AC, Weishaupt JH (2012) A novel phosphorylation site mutation in profilin 1 revealed in a large screen of US, Nordic, and German amyotrophic lateral sclerosis/ frontotemporal dementia cohorts. Neurobiol Aging 1708.e1-1708.e6. CrossRef Medline

Ivanov PA, Chudinova EM, Nadezhdina ES (2003) Disruption of microtubules inhibits cytoplasmic ribonucleoprotein stress granule formation. Exp Cell Res 290:227-233. CrossRef Medline

Ji JY, Haghnia M, Trusty C, Goldstein LSB, Schubiger G (2002) A genetic screen for suppressors and enhancers of the Drosophila Cdk1-cyclin B identifies maternal factors that regulate microtubule and microfilament stability. Genetics 162:1179-1195. Medline

Jockusch BM, Murk K, Rothkegel M (2007) The profile of profilins. Rev Physiol Biochem Pharmacol 159:131-149. CrossRef Medline

Johnson BS, McCaffery JM, Lindquist S, Gitler AD (2008) A yeast TDP-43 proteinopathy model: exploring the molecular determinants of TDP-43 aggregation and cellular toxicity. Proc Natl Acad Sci U S A 105:64396444. CrossRef Medline

Johnson BS, Snead D, Lee JJ, McCaffery JM, Shorter J, Gitler AD (2009) TDP-43 is intrinsically aggregation-prone, and amyotrophic lateral sclerosis-linked mutations accelerate aggregation and increase toxicity. J Biol Chem 284:20329-20339. CrossRef Medline

Ju S, Tardiff DF, Han H, Divya K, Zhong Q, Maquat LE, Bosco DA, Hayward LJ, Brown RH Jr, Lindquist S, Ringe D, Petsko GA (2011) A yeast model of FUS/TLS-dependent cytotoxicity. PLoS Biol 9:e1001052. CrossRef Medline

Kaehler C, Isensee J, Nonhoff U, Terrey M, Hucho T, Lehrach H, Krobitsch S (2012) Ataxin-2-like is a regulator of stress granules and processing bodies. PLoS ONE 7:e50134. CrossRef Medline

Kedersha N, Anderson P (2002) Stress granules: sites of mRNA triage that regulate mRNA stability and translatability. Biochem Soc Trans 30:963969. Medline

Kedersha N, Stoecklin G, Ayodele M, Yacono P, Lykke-Andersen J, Fritzler MJ, Scheuner D, Kaufman RJ, Golan DE, Anderson P (2005) Stress granules and processing bodies are dynamically linked sites of mRNP remodeling. J Cell Biol 169:871-884. CrossRef Medline

Kedersha N, Ivanov P, Anderson P (2013) Stress granules and cell signaling: more than just a passing phase? Trends Biochem Sci 38:494-506. CrossRef Medline

Kim HJ, Kim NC, Wang YD, Scarborough EA, Moore J, Diaz Z, MacLea KS, Freibaum B, Li S, Molliex A, Kanagaraj AP, Carter R, Boylan KB, Wojtas AM, Rademakers R, Pinkus JL, Greenberg SA, Trojanowski JQ, Traynor BJ, Smith BN, et al. (2013) Mutations in prion-like domains in hnRNPA2B1 and hnRNPA1 cause multisystem proteinopathy and ALS. Nature 495:467-473. CrossRef Medline

Klass DM, Scheibe M, Butter F, Hogan GJ, Mann M, Brown PO (2013) Quantitative proteomic analysis reveals concurrent RNA-protein interactions and identifies new RNA-binding proteins in Saccharomyces cerevisiae. Genome Res 23:1028-1038. CrossRef Medline 
Kolobova E, Efimov A, Kaverina I, Rishi AK, Schrader JW, Ham AJ, Larocca MC, Goldenring JR (2009) Microtubule-dependent association of AKAP350A and CCAR1 with RNA stress granules. Exp Cell Res 315:542555. CrossRef Medline

Krogan NJ, Greenblatt JF (2001) Characterization of a six-subunit holoelongator complex required for the regulated expression of a group of genes in Saccharomyces cerevisiae. Mol Cell Biol 21:8203-8212. CrossRef Medline

Kuźma-Kozakiewicz M, Chudy A, Kaźmierczak B, Dziewulska D, Usarek E, Barańczyk-Kuźma A (2013) Dynactin deficiency in the CNS of humans with sporadic ALS and mice with genetically determined motor neuron degeneration. Neurochem Res 38:2463-2473. CrossRef Medline

Kwon S, Zhang Y, Matthias P (2007) The deacetylase HDAC6 is a novel critical component of stress granules involved in the stress response. Genes Dev 21:3381-3394. CrossRef Medline

LaMonte BH, Wallace KE, Holloway BA, Shelly SS, Ascaño J, Tokito M, Van Winkle T, Howland DS, Holzbaur EL (2002) Disruption of dynein/dynactin inhibits axonal transport in motor neurons causing late-onset progressive degeneration. Neuron 34:715-727. CrossRef Medline

Lattante S, Le Ber I, Camuzat A, Brice A, Kabashi E (2012) Mutations in the PFN1 gene are not a common cause in patients with amyotrophic lateral sclerosis and frontotemporal lobar degeneration in France. Neurobiol Aging 1709:e1-e2. CrossRef Medline

Li YR, King OD, Shorter J, Gitler AD (2013) Stress granules as crucibles of ALS pathogenesis. J Cell Biol 201:361-372. CrossRef Medline

Ling SC, Polymenidou M, Cleveland DW (2013) Converging mechanisms in ALS and FTD: disrupted RNA and protein homeostasis. Neuron 79: 416-438. CrossRef Medline

Lipka J, Kuijpers M, Jaworski J, Hoogenraad CC (2013) Mutations in cytoplasmic dynein and its regulators cause malformations of cortical development and neurodegenerative diseases. Biochem Soc Trans 41: 1605-1612. Medline

Liu-Yesucevitz L, Bilgutay A, Zhang YJ, Vanderweyde T, Citro A, Mehta T, Zaarur N, McKee A, Bowser R, Sherman M, Petrucelli L, Wolozin B (2010) Tar DNA binding protein-43 (TDP-43) associates with stress granules: analysis of cultured cells and pathological brain tissue. PLoS ONE 5:e13250. CrossRef Medline

Loschi M, Leishman CC, Berardone N, Boccaccio GL (2009) Dynein and kinesin regulate stress-granule and P-body dynamics. J Cell Sci 122:39733982. CrossRef Medline

Manseau L, Calley J, Phan H (1996) Profilin is required for posterior patterning of the Drosophila oocyte. Development 122:2109-2116. Medline

Michaelsen K, Murk K, Zagrebelsky M, Dreznjak A, Jockusch BM, Rothkegel M, Korte M, Pollard TD (2010) Fine-tuning of neuronal architecture requires two profilin isoforms. Proc Natl Acad Sci U S A 107:1578015785. CrossRef Medline

Michelot A, Costanzo M, Sarkeshik A, Boone C, Yates JR 3rd, Drubin DG (2010) Reconstitution and protein composition analysis of endocytic actin patches. Curr Biol 20:1890-1899. CrossRef Medline

Moore JK, Stuchell-Brereton MD, Cooper JA (2009) Function of dynein in budding yeast: mitotic spindle positioning in a polarized cell. Cell Motil Cytoskeleton 66:546-555. CrossRef Medline

Moseley JB, Sagot I, Manning AL, Xu Y, Eck MJ, Pellman D, Goode BL (2004) A conserved mechanism for Bnil- and mDial-induced actin assembly and dual regulation of Bnil by Bud6 and profilin. Mol Biol Cell 15:896-907. CrossRef Medline

Neumann M, Sampathu DM, Kwong LK, Truax AC, Micsenyi MC, Chou TT, Bruce J, Schuck T, Grossman M, Clark CM, McCluskey LF, Miller BL, Masliah E, Mackenzie IR, Feldman H, Feiden W, Kretzschmar HA, Trojanowski JQ, Lee VM (2006) Ubiquitinated TDP-43 in frontotemporal lobar degeneration and amyotrophic lateral sclerosis. Science 314:130133. CrossRef Medline

Nonhoff U, Ralser M, Welzel F, Piccini I, Balzereit D, Yaspo ML, Lehrach H, Krobitsch S (2007) Ataxin-2 interacts with the DEAD/H-box RNA helicase DDX6 and interferes with P-bodies and stress granules. Mol Biol Cell 18:1385-1396. CrossRef Medline

Oates EC, Rossor AM, Hafezparast M, Gonzalez M, Speziani F, MacArthur DG, Lek M, Cottenie E, Scoto M, Foley AR, Hurles M, Houlden H, Greensmith L, Auer-Grumbach M, Pieber TR, Strom TM, Schule R, Herrmann DN, Sowden JE, Acsadi G, et al. (2013) Mutations in BICD2 cause dominant congenital spinal muscular atrophy and hereditary spastic paraplegia. Am J Hum Genet 92:965-973. CrossRef Medline
Ostrander DB, Ernst EG, Lavoie TB, Gorman JA (1999) Polyproline binding is an essential function of human profilin in yeast. Eur J Biochem 262:2635. CrossRef Medline

Outeiro TF, Lindquist S (2003) Yeast cells provide insight into alphasynuclein biology and pathobiology. Science 302:1772-1775. CrossRef Medline

Puls I, Jonnakuty C, LaMonte BH, Holzbaur EL, Tokito M, Mann E, Floeter MK, Bidus K, Drayna D, Oh SJ, Brown RH Jr, Ludlow CL, Fischbeck KH (2003) Mutant dynactin in motor neuron disease. Nat Genet 33:455456. CrossRef Medline

Ralser M, Albrecht M, Nonhoff U, Lengauer T, Lehrach H, Krobitsch S (2005) An integrative approach to gain insights into the cellular function of human ataxin-2. J Mol Biol 346:203-214. CrossRef Medline

Ramaswami M, Taylor JP, Parker R (2013) Altered ribostasis: RNA-protein granules in degenerative disorders. Cell 154:727-736. CrossRef Medline

Reijns MA, Alexander RD, Spiller MP, Beggs JD (2008) A role for Q/N-rich aggregation-prone regions in P-body localization. J Cell Sci 121:24632472. CrossRef Medline

Renton AE, Chiò A, Traynor BJ (2014) State of play in amyotrophic lateral sclerosis genetics. Nat Neurosci 17:17-23. CrossRef Medline

Satterfield TF, Jackson SM, Pallanck LJ (2002) A Drosophila homolog of the polyglutamine disease gene SCA2 is a dosage-sensitive regulator of actin filament formation. Genetics 162:1687-1702. Medline

Schliwa M, Ezzell RM, Euteneuer U (1984) Erythro-9-[3-(2-hydroxynonyl) ] adenine is an effective inhibitor of cell motility and actin assembly. Proc Natl Acad Sci U S A 81:6044-6048. CrossRef Medline

Sheeman B, Carvalho P, Sagot I, Geiser J, Kho D, Hoyt MA, Pellman D (2003) Determinants of S. cerevisiae dynein localization and activation: implications for the mechanism of spindle positioning. Curr Biol 13:364372. CrossRef Medline

Sheth U, Parker R (2003) Decapping and decay of messenger RNA occur in cytoplasmic processing bodies. Science 300:805-808. CrossRef Medline

Simpson CL, Lemmens R, Miskiewicz K, Broom WJ, Hansen VK, van Vught PW, Landers JE, Sapp P, Van Den Bosch L, Knight J, Neale BM, Turner MR, Veldink JH, Ophoff RA, Tripathi VB, Beleza A, Shah MN, Proitsi P, Van Hoecke A, Carmeliet P, et al. (2009) Variants of the elongator protein 3 (ELP3) gene are associated with motor neuron degeneration. Hum Mol Genet 18:472-481. CrossRef Medline

Suetsugu S, Miki H, Takenawa T (1998) The essential role of profilin in the assembly of actin for microspike formation. EMBO J 17:6516-6526. CrossRef Medline

Sun Z, Diaz Z, Fang X, Hart MP, Chesi A, Shorter J, Gitler AD (2011) Molecular determinants and genetic modifiers of aggregation and toxicity for the ALS disease protein FUS/TLS. PLoS Biol 9:e1000614. CrossRef Medline

Surma MA, Klose C, Peng D, Shales M, Mrejen C, Stefanko A, Braberg H, Gordon DE, Vorkel D, Ejsing CS, Farese R Jr, Simons K, Krogan NJ, Ernst $\mathrm{R}$ (2013) A lipid E-MAP identifies Ubx2 as a critical regulator of lipid saturation and lipid bilayer stress. Mol Cell 51:519-530. CrossRef Medline

Tardiff DF, Jui NT, Khurana V, Tambe MA, Thompson ML, Chung CY, Kamadurai HB, Kim HT, Lancaster AK, Caldwell KA, Caldwell GA, Rochet JC, Buchwald SL, Lindquist S (2013) Yeast reveal a "druggable" Rsp5/Nedd4 network that ameliorates $\alpha$-synuclein toxicity in neurons. Science 342:979-983. CrossRef Medline

Tiloca C, Ticozzi N, Pensato V, Corrado L, Del Bo R, Bertolin C, Fenoglio C, Gagliardi S, Calini D, Lauria G, Castellotti B, Bagarotti A, Corti S, Galimberti D, Cagnin A, Gabelli C, Ranieri M, Ceroni M, Siciliano G, Mazzini L, et al. (2012) Screening of the PFN1 gene in sporadic amyotrophic lateral sclerosis and in frontotemporal dementia. Neurobiol Aging 34:1517.e9_ 1517.e10. CrossRef Medline

Tong AH, Boone C (2006) Synthetic genetic array analysis in Saccharomyces cerevisiae. Methods Mol Biol 313:171-192. Medline

Tong AH, Evangelista M, Parsons AB, Xu H, Bader GD, Pagé N, Robinson M, Raghibizadeh S, Hogue CW, Bussey H, Andrews B, Tyers M, Boone C (2001) Systematic genetic analysis with ordered arrays of yeast deletion mutants. Science 294:2364-2368. CrossRef Medline

Tourrière H, Chebli K, Zekri L, Courselaud B, Blanchard JM, Bertrand E, Tazi J (2003) The RasGAP-associated endoribonuclease G3BP assembles stress granules. J Cell Biol 160:823-831. CrossRef Medline

Treusch S, Hamamichi S, Goodman JL, Matlack KE, Chung CY, Baru V, Shulman JM, Parrado A, Bevis BJ, Valastyan JS, Han H, Lindhagen- 
Persson M, Reiman EM, Evans DA, Bennett DA, Olofsson A, DeJager PL, Tanzi RE, Caldwell KA, Caldwell GA, et al. (2011) Functional links between $\mathrm{A} \beta$ toxicity, endocytic trafficking, and Alzheimer's disease risk factors in yeast. Science 334:1241-1245. CrossRef Medline

Tsai NP, Tsui YC, Wei LN (2009) Dynein motor contributes to stress granule dynamics in primary neurons. Neuroscience 159:647-656. CrossRef Medline

van Blitterswijk M, Baker MC, Bieniek KF, Knopman DS, Josephs KA, Boeve B, Caselli R, Wszolek ZK, Petersen R, Graff-Radford NR, Boylan KB, Dickson DW, Rademakers R (2013) Profilin-1 mutations are rare in patients with amyotrophic lateral sclerosis and frontotemporal dementia. Amyotroph Lateral Scler Frontotemporal Degener 14:463-469. CrossRef Medline

Van der Veen AG, Schorpp K, Schlieker C, Buti L, Damon JR, Spooner E, Ploegh HL, Jentsch S (2011) Role of the ubiquitin-like protein Urm1 as a noncanonical lysine-directed protein modifier. Proc Natl Acad Sci U S A 108:1763-1770. CrossRef Medline

Witke W, Podtelejnikov AV, Di Nardo A, Sutherland JD, Gurniak CB, Dotti C, Mann M (1998) In mouse brain profilin I and profilin II associate with regulators of the endocytic pathway and actin assembly. EMBO J 17:967-976. CrossRef Medline
Wittenmayer N, Rothkegel M, Jockusch BM, Schlüter K (2000) Functional characterization of green fluorescent protein-profilin fusion proteins. Eur J Biochem 267:5247-5256. CrossRef Medline

Wolozin B (2012) Regulated protein aggregation: stress granules and neurodegeneration. Mol Neurodegener 7:56. CrossRef Medline

Wolven AK, Belmont LD, Mahoney NM, Almo SC, Drubin DG (2000) In vivo importance of actin nucleotide exchange catalyzed by profilin. J Cell Biol 150:895-904. CrossRef Medline

Wu CH, Fallini C, Ticozzi N, Keagle PJ, Sapp PC, Piotrowska K, Lowe P, Koppers M, McKenna-Yasek D, Baron DM, Kost JE, Gonzalez-Perez P, Fox AD, Adams J, Taroni F, Tiloca C, Leclerc AL, Chafe SC, Mangroo D, Moore MJ, et al. (2012) Mutations in the profilin 1 gene cause familial amyotrophic lateral sclerosis. Nature 488:499-503. CrossRef Medline

Yang S, Fifita JA, Williams KL, Warraich ST, Pamphlett R, Nicholson GA, Blair IP (2013) Mutation analysis and immunopathological studies of PFN1 in familial and sporadic amyotrophic lateral sclerosis. Neurobiol Aging 34:2235.e7-2235.e10. CrossRef Medline

Zou ZY, Sun Q, Liu MS, Li XG, Cui LY (2013) Mutations in the profilin 1 gene are not common in amyotrophic lateral sclerosis of Chinese origin. Neurobiol Aging 34:1713.e5-1713.e6. CrossRef Medline 